\title{
The Forgotten Marxist Theory of Communication \& Society
}

\author{
Horst Holzer
}

\section{Translated from German into English by Christian Fuchs}

\begin{abstract}
Marxist political economy of communication analyses the role of communication in society and capitalism. This paper shows what it means to take a historical and materialist approach for analysing communication and society. In the German-speaking world, Marxist communication research has largely remained a "forgotten theory".

First, the paper analyses the role of communication in society, which requires thinking of how communication relates to work and production. Second, the paper analyses the emergence of communication in capitalist society. It shows that there is a close interaction of the dominant type of capitalism and the emergence and development of new means of communication. Third, the paper points out five roles of the media in capitalism (the production and sale of media products, advertising and commodity circulation, the legitimation of domination, regeneration and reproduction of labour-power, market for media technologies) and engages with how ideology, social psychology, audiences' habitus and everyday practices/life interact in the reception of media contents, especially news programmes.

The preface to this article, written by the translator, presents aspects of the works of Horst Holzer. Given his pioneering intellectual role in the development of the critique of the political economy of communication in the German-speaking world, it is not an understatement to say that Horst Holzer is Germany's Dallas Smythe.
\end{abstract}

Keywords: Horst Holzer, communication, society, theory, Marx, Marxism, critique of political economy

\section{Acknowledgement:}

First published in German as book chapter:

Holzer, Horst. 1994. Kapitel IV: Eine „vergessene Theorie“ gesellschaftlicher Kommunikation? (Bezugspunkt: Historisch-materialistische Gesellschaftswissenschaft). In Medienkommunkation: Einführung in handlungs- und gesellschaftstheoretische Konzeptionen, 185-221. Opladen: Westdeutscher Verlag. ISBN 978-3-531-22172-4. (c) Westdeutscher Verlag GmbH, Opladen 1994. Translated and published with permission of Springer Nature.

\section{Preface: Horst Holzer's Marxist Theory of Communication}

\section{Christian Fuchs}

\section{Who Was Horst Holzer?}

Horst Holzer (1935-2000) was a German sociologist and communication theorist. He contributed to the formation and development of the critique of the political economy of media and communication in the German-speaking world. Holzer used Marxist theory for the analysis of the relationship between capitalism and communication. Given his pioneering intellectual role in the development of the critique of the political economy of communication in the German-speaking world, it is not an understatement to say that Horst Holzer is Germany's Dallas Smythe. Holzer lived and worked in Munich and published twenty German books. The focus of Holzer's writings was 
on communication theory, the sociology of communication, as well as on capitalism and communication. In particular, his books were about the ideology and political economy of magazines, newspapers, radio and television; public sphere theory, sociological theories, children and television, and surveillance.

Horst Holzer studied economics, sociology, political science and psychology in Wilhelmshaven, Frankfurt, and Munich. He obtained a PhD at the Ludwig Maximilian University of Munich with a dissertation that held the title Selbstverständnis und Inhaltsstruktur aktueller Illustrierter: Dargestellt an den Zeitschriften Quick, Revue, Stern [Self-Understanding and Content Structure of Contemporary Magazines: The Magazines Quick, Revue, Stern]. The sociologist Karl Martin Bolte was his PhD supervisor. The dissertation analysed the role of magazines in capitalism. Holzer defended his habilitation in 1970 and obtained a venia legendi in sociology. The habilitation was published in 1971 under the title Gescheiterte Aufklärung? Politik, Ökonomie und Kommunikation in der Bundesrepublik Deutschland [Failed Enlightenment? Politics, Economy and Communication in the Federal Republic of Germa$n y]$. The work analysed how the media system in Germany did not bring about the enlightenment it promised. It is an analysis of communications' role in capitalist society.

For the study of capitalism and communication, Holzer's two most important books are Kommunikationssoziologie (Sociology of Communication) (Holzer 1973) and Medienkommunikation: Einführung in handlungs- und gesellschaftstheoretische Konzeptionen (Mediated Comunication: Introduction to Concepts of Action Theory and Theories of Society) (Holzer 1994). The article translated and published by tripleC was originally printed as the fourth chapter in Holzer's 1994 book. The article provides a good introduction to Holzer's analysis of communication's role in society and capitalism. Only one of Holzer's books was fully translated into another language, namely Kommunikationssoziologie that in 1978 appeared as Sociología de la comunicación in Spanish. To my knowledge, besides the tripleC article only three works by Holzer are available in English, namely three essays published in the journal Media, Culture \& Society (Holzer 1985a, 1983, 1980). Holzer's works have thus far remained internationally little known. tripleC's translation and publication of the most important chapter from one of Holzer's key books wants to help making his work and the forgotten and undiscovered German tradition of critical political economy of communication more widely known.

But German critical political economy of communication is also forgotten in another, more political sense: The field could not be properly institutionalised because its representatives have often faced political repression. In 1972, the German government under the Social Democratic Chancellor Willy Brandt passed a law that introduced a decree that allowed banning people, who held radical political positions, from working in public institutions. The decree became known as Berufsverbot (Professional Ban) or Radikalenerlass (Anti-Radical Decree). The professional ban concerned especially members of the German Communist Party (DKP). Thousands of communists lost their public service jobs or were banned from taking up public service employment.

Horst Holzer was a long-time member of the DKP. In 1971, Holzer applied for a full professorship in the field of aesthetics and communication at the University of Bremen. He was ranked on the first position. Because of his DKP membership, the local government denied hiring Holzer. He became an academic victim of the communist ban (Bönkost 2011, Scheu 2012; Kommittee für Grundrechte und Demokratie 1982, 43). Holzer's case was the trigger for the general, Germany-wide introduction of the 
professional ban in January 1972 (Kommittee für Grundrechte und Demokratie 1982, 43). The Office for the Protection of the Constitution argued that membership of the DKP stood in a contradiction to the free democratic basic order guaranteed by the German Constitution. This means that one assumed the DKP and its members opposed and were a threat to democracy. The local Social Democratic (SPD) government in Bremen denied Holzer the won professorship. The ban from the professorship in Bremen also resulted in further executions of the professional ban against Holzer when committees wanted to appoint him to professorships in Oldenburg, Berlin, and Marburg. In 1974, the ban resulted in Holzer being denied tenure at the Ludwig Maximilian University of Munich, where he had worked as research assistant from 1964 until 1970 and had become a C3-professor in 1971. The denial of tenure resulted in the end of Holzer's employment in Munich. He from then on was factually without fixed academic employment and was an occasional adjunct lecturer in Bremen, Berlin, and Klagenfurt. Wolfgang Abendroth (1975) argues that Holzer's professional ban was a "direct violation of the German Basic Law"1 (244), that in the democratic system of countries such as Britain, Italy, France, Benelux and Scandinavian countries a professional ban against communist university teachers would be considered as anti-democratic (245), and that the ban of communists from public services repeated Bismarck's Anti-Socialist Laws introduced in 1878 and the Nazis' ban of socialist and communist parties (243-249, 295-302).

Predominantly former members of the German Communist Party (KPD) that had been outlawed in 1956 founded the DKP in 1968. The DKP did not have a party programme until 1978. But in 1968, it published a programme draft that committed the Party to democracy. The draft programme for example said: "For the restructuring of Germany into a state of progressive democracy: [...] It is the first duty of all socialists to campaign to support the defence and advancement of democratic rights, social security, and peace"2. Given such a democratic focus, it is surprising that the DKP and its members were considered as being anti-democratic. Horst Holzer commented on the professional ban: "These educational and professional bans are the outflow of state action that proceeds according to the maxim: Those who do not honour the capitalist order, do not deserve democratic freedom. [...] The answer to the question 'What is the point of the professional ban?' can only be: 'The point is to abolish it'”3 (Holzer 1981, 21, 24). "The possibilities for Marxist social scientists to participate [in Germany] in the academic institutionalisation and the socio-practical proliferation of sociology are few and far between. The reasons are the prevalent post-war-anticommunism, the destruction of the Communist Party of Germany (KPD), and the current educational and professional bans (Also the German Sociological Association

\footnotetext{
1 Translation from German: „unmittelbaren Verletzung des Verfassungsrechtes“.

${ }^{2}$ German original: „Für die Umgestaltung der Bundesrepublik zu einem Staat der fortschrittlichen Demokratie und des Friedens [...] Es ist die erste Pflicht aller Sozialisten, sich für die Verteidigung und Erweiterung der demokratischen Rechte, für soziale Sicherheit, für den Frieden einzusetzen", http://berufsverbote.de/tl files/docs/KPD-Programmentwurf1968.pdf, accessed on July 5, 2017.

${ }^{3}$ German original: „Denn diese Ausbildungs- und Berufsverbote sind Ausflüsse eines staatlichen Handelns, das nach der Maxime verfährt: Wer die Kapitalordnung nicht ehrt, ist die demokratische Freiheit nicht wert. [...] kann die Antwort auf die Frage: ,Wozu sind die Berufs- und Ausbildungsverbote da?' nur lauten: ,Zum Abschaffen'”.
} 
DGS and the Professional Association of German Sociologists BDS 'behave' in a reactionary manner in cases of sociologists' professional ban)"4 (Holzer 1985b, 134).

Since the middle of the 1980s, German federal states subsequently abolished the professional ban-decrees. Relics of it, however, still exist today and have for example in 2016 in Munich (Bavaria) resulted in discussions and a formal process about whether DKP member Kerem Schamberger should be awarded a PhD scholarship or not (Schamberger 2017). The example of Horst Holzer shows that in the Germanspeaking world, critical political economy of communication has been structurally silenced and its institutionalisation has been circumvented.

It is unfortunate that in the German-speaking world, Horst Holzer is much more known for the repression he faced than for his academic writings. Making a real difference requires us to engage with and further develop the foundations of German critical political economy of communication. Translating and publishing one of Holzer's texts is a contribution to this task.

\section{Horst Holzer's Works: Capitalism \& Communication}

Horst Holzer combined critical theory and empirical social research in the analysis of media and communication's political economy. His critique of the political economy of media/communication is based on the dialectic of theory and empirical research. Holzer for example used content analysis or the secondary analysis of empirical studies and macro-economic data in order to analyse how communication, the capitalist economy and democracy were connected (see Holzer 1971). Comparable to Jürgen Habermas (1991), Holzer stresses that advertising, media concentration, the media's commercial orientation, "the personalisation of facts about society" and the "marked amalgamation of individual life problems and public affairs" (Holzer 1971, 151) undermine the public sphere's democratic character. One difference between Habermas and Holzer is that the latter did not make arguments purely based on social theory and philosophy, but also interpreted empirical data/results with the help of a critical theory of communication and society.

Holzer's theory of communication and society came into being as a critique of action theory and systems theory. In respect to systems theory, an approach that was internationally in the social sciences especially advanced by Talcott Parsons, Holzer criticises that this approach conceives of social systems as subjects (cp. Holzer 1971, 255) and "hypostatises an actual historical status quo as society's order as such"5 (Holzer 1971, 250). Talcott Parson's approach was one of the starting points for Niklas Luhmann's social systems theory. Internationally, Luhmann is not considered as one of the $20^{\text {th }}$ century key social theorists. In Germany, he in contrast has been one of the most influential $20^{\text {th }}$ century sociologists. Luhmann advanced a functionalist theory of society that fused the notions of communication and autopoiesis. For Luhmann (1995), society is a self-reproducing communication system, in which one communication produces the next communication in an endless self-reproducing loop.

\footnotetext{
${ }^{4}$ German original: „Aufgrund des Nachkriegs-Antikommunismus, der KPD-Zerstörung, der aktuellen Ausbildungs- und Berufsverbote sind für marxistische Gesellschaftswissenschaftler die Möglichkeiten sehr dünn gesät, sich an der akademischen Einrichtung und gesellschaftspraktischen Profilierung der Soziologie zu beteiligen. (Auch DGS und BDS ,verhalten' sich in Berufsverbotsfällen, die Soziologen betreffen, tief reaktionär“.

${ }^{5}$ Translation from German: „die Hypostasierung eines realgesellschaftlichen Status quo zur Ordnung von Gesellschaft schlechthin“.
} 
Holzer (1985b) argued that German sociology was after 1945 strongly influenced by American functionalism. He criticises that Luhmann's systems theory is not able to illuminate the connection of communication, body and mind as well as how "mass communication's genesis, quality structure and functions" 6 are entangled with media production, media organisations, media contents, media use, media reception, and human consciousness (Holzer 1994, 182). Luhmann's theory is for Holzer (1985b, 130) "system fetishism"7 (Holzer 1985b, 130).

Jürgen Habermas' $(1984,1987)$ theory of communicative action is an actiontheoretical alternative to Niklas Luhmann's functionalist theory of communication. Holzer also profoundly engaged with Habermas' approach. He criticises that Habermas' theory does not conceive of the relation between work and interaction as a dialectic, but rather as a dualism (see Holzer 1987). Habermas is "not capable to discern the essential quality of societal production: In the process of production, we not just develop the productive forces, but also societal relations, including communication and interaction, that humans enter in this production process"” (Holzer 1987, 27). Holzer (1988, 1000-1001) argues that Habermas' dualistic approach is reflected in the separation of system and lifeworld. For Holzer (1988), production is the foundational feature of society. He argues for a dialectical "mediation of production and communication"'. Holzer $(1975,23)$ says that communication has a "constitutive role"10 in society in the "co-operating humans' appropriation of nature" and the "interpersonal interaction and understanding - which both are processes that have to count as particular sides of society's historically developing constitutive context"11. That there is a dialectic of production and communication means for Holzer (1975, $30)$ that "humans produce communicatively and communicate productively and thereby create the unity of their relation to nature and to themselves" ${ }^{12}$. This insight has also been formulated by two other Marxist theorists - Lukács and Williams. Georg Lukács has in his Ontology of Social Being in contrast to Habermas characterised production in society as a dialectic of work and communication (see Fuchs 2016a, chapter 2). Lukács has in this context coined the notion of teleological positing. Like Lukács, also Raymond Williams (1977) has provided insights of how the dialectic of production and communication can be understood in a materialist manner

\footnotetext{
${ }^{6}$ Translation from German: „die Verschränkung von Genese, Beschaffenheit und Funktion der Massenkommunikation".

${ }^{7}$ Translation from German: „Systemfetischismus“.

${ }^{8}$ Translation from German: Habermas ist "nicht imstande, die wesentliche Bestimmung der gesellschaftlichen Produktion zu erkennen: daß im Prozeß der Produktion eben nicht nur die Produktivkräfte entwickelt werden, sondern auch die gesellschaftlichen Beziehungen - eingeschlossen: ,Kommunikation', ,Interaktion' -, die die Menschen in diesem Produktionsprozeß miteinander eingehen".

${ }^{9}$ Translation from German: „Vermitteltheit von Produktion und Kommunikation“.

${ }^{10}$ Translation from German: „konstituierende Funktionen“

${ }^{11}$ Translation from German: „> Gesellschaftliche Kommunikation< muß dabei unter zwei wechselseitig aufeinander zu beziehenden, weil real dialektisch verschränkten Aspekten analysiert werden: einerseits hinsichtlich ihrer Funktion im Prozeß der Naturaneignung durch kooperierende Menschen, andererseits hinsichtlich ihrer Funktion im Prozeß der innergesellscahftlichen, zwischenmenschlichen Auseinandersetzung und Verständigung - beides Prozesse, die als besondere Seiten des sich historisch entwickelnden gesellschaftlichen Konstitutionszusammenhangs zu gelten haben".

${ }^{12}$ Translation from German: „Das heißt aber - knapp und lapidar formuliert - nichts anderes, als daß die Menschen kommunizierend produzieren und produzierend kommunizieren und so die Einehit ihres Verhältnisses zur Natur und zu sich selbst herstellen“.
} 
(for a detailed discussion, see: Fuchs Forthcoming; Fuchs 2016a; Fuchs 2015, chapters 2 \& 3 ).

Holzer worked on a materialist theory of communication that he grounded in Marx's social theory. He argues that there is a dialectic of work and communication. "Knowledge and communication" are "two sides of the process that regulates the metabolism of society and nature as well as society's internal relations"13 (Holzer 1973, 57). The decisive feature of this theory is that it is a critique of the political economy of media/communication. Holzer analyses communication and media's roles in society at the level of individual capital and total capital (see: Holzer 1973, 129-137; Holzer 1994, 202-204). At the level of individual capital, the media and communication system has its own capitalist economy, in which information is a direct form of capital valorisation and surplus-value production. At the same level, the media play a role in the circulation of commodities and create for the "a climate fostering consumption and the advertisement of specific products and services" ${ }^{\text {"14 }}$ (Holzer 1994, 202). At the level of the capitalist totality, the communication system has an ideological role in "securing and legitimatising capitalist domination"15 (Holzer 1973, 131) and "society's organisational principle"16 (Holzer 1994, 202). At the level of capitalist totality, capitalist media also have a reproductive role as source of information and entertainment in labour-power's "production, maintenance and reproduction"17 (Holzer 1973, 131).

Holzer was an avid reader and closely followed and commented on discussions in social research and communication studies. A good example is his book Soziologie in der BRD: Theorienchaos und Ideologieproduktion (Sociology in the Federal Republic of Germany: Theory Chaos and Ideology Production) (Holzer 1982). In this book, Holzer comments on the Theorienvergleich (Comparison of Theories), a debate that took place in the 1970s in the German Sociological Association (DGS). Sociologists representing behavioural theory, systems theory, action theory, Habermas' critical theory and Marxist theory discussed theoretical differences. Holzer follows Karl Hermann Tjaden, who in the comparison of theories represented the Marxist position. Holzer argues that the other positions neglect that society is the "communicative-co-operative performance of action that produces human living conditions and the 'production' of moments that shape the performance of action" ${ }^{18}$ and a connexion of productive forces and relations of production (Holzer 1982, 39).

Holzer's essay published in tripleC is a translation of the last chapter in his final book Medienkommunikation: Einführung in handlungs- und gesellschaftstheoretische Konzeptionen (Holzer 1994). Holzer in this book builds on his previous engagement with various social theories and discusses in depth diverse theories of communication, namely action-theoretic perspectives in chapter 1 (Karsten Renckstorf, Ben Bachmair, Michael Charlton/Klaus Neumann-Braun), Habermas' theory of communicative action in chapter 2, and Luhmann's communicative system theory in chapter 3.

\footnotetext{
${ }^{13}$ Translation from German: „Erkenntnis und Kommunikation sind zwei Seiten des Prozesses, der den gesellschaftlich organisierten Stoffwechsel mitder Natur und die innergesellschaftliche Auseinandersetzung regelt".

${ }^{14}$ German original: „Verbreitung von ,Konsumklima' und ,Bewerbung' spezifischer Produkte und Dienstleistungen".

${ }^{15}$ Translation from German: „zur Sicherung und Legitimation der Kapitalherrschaft“.

${ }^{16}$ Translation from German: "des gesellschaftlichen Ordnungsprinzips“.

17 Translation from German: "Herstellung, Erhaltung und Wiederherstellung“.

18 Translation from German: "der kommunikativ-kooperative Handlungsvollzug, durch den die Lebensbedingungen der Menschen geschaffen und dann selber wieder als den Handlungsvollzug bestimmende Momente ,verarbeitet' werden".
} 
Chapter 4 - the translated chapter published in tripleC - presents Holzer's alternative to these approaches, a Marxist theory framework for understanding communication, capitalism and society.

Holzer's essay published in triple $C$ commences the analysis with a section focused on the role of communication in society. Holzer's starting point is Marx's German Ideology, a work that ascertains that society is based on human being's social production. Holzer stresses that communication is the medium and result of human action and production. He criticises that Habermas and Luhmann do not adequately ground the analysis of society and communication in the realm of work (see Fuchs 2015 and Fuchs 2016a for a detailed discussion).

The essay's second section focuses on capitalism and communication. Holzer analyses the co-development of capitalism and the means of communication. The emergence of merchant capitalism, industrial capitalism, and imperialism/monopoly capitalism advanced and interacted with the development of new technologies such as the commercial press in merchant capitalism; the telegraph, railways and steamships in industrial capitalism; and commercial mass media focused on advertising and consumer capitalism in monopoly capitalism. When analysing the relationship of the economy and technology, it is important to avoid technological reductionism. Such one-dimensional arguments that can for example be found in long-wave theories of economic development and theories of the post-industrial society that argue that new technologies bring about new phases of economic and societal development (for a contemporary critique of such approaches see Fuchs 2016b). But modern technology does not develop independently from the capitalist economy and capitalist society. There is a dialectic of technological development and society. Technologies do not come into existence arbitrarily, but because their development is stimulated by economic, political and ideological interests, strategies and agendas. But society only conditions, but cannot determine technological development. The latter has a relative autonomy and tends to bring about unintended features, impacts and consequences, to which society needs to react. The emergence of the Internet in late $20^{\text {th }}$ century capitalism has interacted with the development of post-Fordist, neoliberal, financial capitalism (Fuchs 2008, 2017).

In the essay's third, longest section, Horst Holzer discusses foundations of communications' political economy and the social psychology of media audiences. Holzer's general understanding of a materialist analysis of society is that it investigates communication in the context of the economic system, political/state organisations, and ideology. Holzer identifies five "functions" the media and communication system takes on in capitalist societies. Comparing Holzer's $(1973,129)$ book Kommunikationssoziologie with the tripleC-essay that was first published in German in Holzer's (1994, chapter IV) book Medienkommunikation shows that he increased the number of these functions from four to five. The media system in capitalism is a sphere for the sale of communication commodities, a sphere that helps advertising commodities and stimulating commodity consumption, a sphere of ideological legitimation, a sphere that helps reproducing labour-power, and a sphere that stimulates the purchase of media technologies.

Holzer in the essay that triple $C$ translated analyses these five capitalist roles of the media in respect to the press, public service broadcasting, and commercial broadcasting. In the early 1990s, when Holzer wrote this paper, the Internet existed, but was not broadly used. The Internet became widely adopted during the 1990s, when the World Wide Web (WWW) developed in the context of neoliberalism and the new imperialism into an ever more popular, commercial and user-friendly information and 
communication system. Today, we can therefore add the Internet as a means of communication to Holzer's analysis (see table I).

\begin{tabular}{|c|c|}
\hline & Internet \\
\hline Organisational form & $\begin{array}{l}\text { Dominance by online corporations that use the Internet as } \\
\text { tool for targeted advertising and commercial purposes (e.g. } \\
\text { Google/YouTube, Facebook, Baidu, Yahoo, QQ, Amazon, } \\
\text { Taobao/TMall, Twitter, Weibo, etc.). } \\
\text { Also traditional publishers use the Internet as a publishing } \\
\text { and advertising platform. } \\
\text { There are also non-commercial Internet platforms and tech- } \\
\text { nologies that are operated on a non-profit basis (e.g. Wikipe- } \\
\text { dia, WikiLeaks, non-profit open access publishers, alternative } \\
\text { online news platforms, }\end{array}$ \\
\hline Steering principle & $\begin{array}{l}\text { Dominant principle: Capitalist profit-orientation, profit maximi- } \\
\text { sation; }\end{array}$ \\
\hline \multicolumn{2}{|l|}{ Capitalist roles: } \\
\hline Economy & $\begin{array}{l}\text { Online sale of targeted advertisements, digital goods, non- } \\
\text { digital goods and services, access to online con- } \\
\text { tents/services/platforms, digital labour. Non-profit online activ- } \\
\text { ities form a minority sphere that has a subordinated role. }\end{array}$ \\
\hline $\begin{array}{l}\text { Commodity circula- } \\
\text { tion }\end{array}$ & $\begin{array}{l}\text { Targeted advertising is capitalist Internet platforms' dominant } \\
\text { capital accumulation model. There are online shopping plat- } \\
\text { forms such as Amazon, eBay, or TMall/Taobao. The capitalist } \\
\text { Internet is a large shopping mall and advertising space. It } \\
\text { helps creating a climate of commodity consumption. It pro- } \\
\text { motes commodities and thereby plays an important role in the } \\
\text { circulation of commodities and capital. } \\
\text { To a certain degree, users block advertisements and there } \\
\text { are online gift platforms for gifting that oppose the principles } \\
\text { of commodity sales and capital accumulation. }\end{array}$ \\
\hline Domination & $\begin{array}{l}\text { The Internet is a sphere for the circulation of dominant ideo- } \\
\text { logies, user-generated ideologies, tabloid news and culture } \\
\text { (e.g. "fake news"). It is also a sphere of economic and politi- } \\
\text { cal surveillance. To a certain degree, users make use of the } \\
\text { Internet as means of protest and alternative information, } \\
\text { communication and organisation that challenges capitalist } \\
\text { power and state power. }\end{array}$ \\
\hline $\begin{array}{l}\text { Regeneration and } \\
\text { reproduction of la- } \\
\text { bour-power }\end{array}$ & $\begin{array}{l}\text { Being online has become one of the most common everyday } \\
\text { activities that in many respects is a context of the reproduc- } \\
\text { tion of labour-power through information, entertainment, and } \\
\text { communication. The Internet is both a sphere of labour and } \\
\text { leisure. On the Internet, the boundaries between la- } \\
\text { bour/leisure, production/consumption, public/private tend to } \\
\text { blur. }\end{array}$ \\
\hline $\begin{array}{l}\text { Media sales and me- } \\
\text { dia markets }\end{array}$ & $\begin{array}{l}\text { The Internet stimulates the development and purchase of } \\
\text { digital devices }\end{array}$ \\
\hline
\end{tabular}

Table I: Application of Horst Holzer's five roles of the media in society to the Internet

In respect to the role of ideology in capitalism, Holzer (1975, chapter 2) stresses the importance of commodity fetishism in Marxist analysis. He argues that the fetishism of commodities, money and wages results in the existence of the ideologies of price consciousness, performance, competition, merit, and the appearance of the private 
sphere as autonomous from alienation and shaped by interpersonal sympathy. Commodity fetishism as constitutive principle of capitalism would also result in "the communicative character of commodities and the commodity character of communication that form the basis of an illusory total societal synthesis: illusory because this synthesis [...] is the expression of a mode of production in which the societalisation of labouring subjects takes places so to speak when the day's work is done and is therefore not experienced as made and therefore changeable social relation, but as quasi-law of nature and fateful undoing" ${ }^{19}$ (Holzer 1975, 45)

Given that Holzer's speaks of five "functions" of the media system in capitalism, the impression can emerge that he conceives of the media only in "negative" terms as tool of domination, exploitation and ideological propaganda. Holzer, however, makes clear that the five dimensions have to do with the capitalist use of the means of communication. He again and again in his writings points out that capitalist use is not static and all-encompassing, but dynamic and subject to contradictions. A response to critics of Holzer's approach is therefore that his typology focuses only on the capitalist part of communications that stands in a contradiction to non-capitalist communications and non-capitalist uses of communications that are not mapped in the typology because they are considered to have a non-capitalist character. So one should certainly see alternative, non-capitalist media, the use of communications as means of anti-capitalist struggles, and the audience's potential resistance to manipulation and ideology as important dimensions of the critique of the political economy of media/communication (Fuchs 2011).

Holzer and Schmid (1972) discuss alternatives to capitalist media. "The decisive precondition of a qualitative transformation in the real of the mass media is the creation of a political public sphere" (Holzer and Schmid 1972, 129). They suggest the creation of a non-profit newspaper organised and funded by trade unions; the transition to self-managed media companies that are based on the participation of journalist collectives and audience collectives in decision-making; the political control of horizontal, vertical and diagonal media concentration; the decartelisation and expropriation of media monopoly capital; the creation of media advertising co-operatives, in which media organisations deal collectively with advertising clients so that monopoly capital does not achieve privileges; the transformation of capitalist media into public service media along with the establishment of media workers' and audiences' collective participation. Such transformations would require "politics of participation and enlightening educational work" (Holzer and Schmid 1972, 135).

Holzer (1975, 179-190) sees alternative media in the context of class and social struggles: Based on Negt and Kluge (1993), he argues for the alternative use of television in order to constitute a proletarian public sphere. Based on Bert Brecht (1932/2000), he argues for television to be turned into a medium, in which viewers become producers. The goal would be the "'de-capitalisation' of broadcasting corporations" 20 (Holzer 1975, 184). Decisive would be the use of alternative media in the

\footnotetext{
19 Translation from German: „[...] daß der Kommunikativ-Charakterder Waren und der Warencharakter der Kommunikation die Basis einer scheinhaften gesamtgesellschaftlichen Synthese abgeben; scheinhaft deshalb, weil die Synthese [...] Ausdruck einer Produktionsweise ist, in der die Vergesellschaftung der arbeitenden Subjekte immer nur nachträglich, sozusagen nach getaner Arbeit sich ereignet und dementsprechend als quasi-naturgesetzliches, schicksalhaftes Verhängnis, nicht aber als gemachter und daher veränderbarer Sozialzusammenhang erlebt wird“.

${ }^{20}$ Translation from German: „> Entkapitalisierung< der Funkanstalten“.
} 
political praxis of anti-capitalist movements, trade unions, and left-wing political parties.

Horst Holzer's suggestions for the creation of non-capitalist media remain highly topical today. They are guided by Marx's $(1842,175)$ categorical communication imperative that the "primary freedom of the press lies in not being a trade".

Various Cultural Studies and cultural theory approaches have stressed that there is no necessary correspondence between meanings encoded to the media that represent dominant groups' ideologies and the meanings that audiences and users produce in the reception process. Holzer deals with issues of reception, psychology and ideology in section 3.3 of the essay published in tripleC.

Holzer's analysis is in this context particularly influenced by Pierre Bourdieu's (1984) concept of the habitus. Holzer stresses that media audiences' members are not simply brainwashed and manipulated by capitalist corporations, but that the expectations they have in respect to the media are shaped by their material conditions and experiences in everyday life. The strength of Bourdieu's analysis is that he stresses that society neither means individual activities nor determination of humans by impersonal structures, but rather a constant productive interaction of humans and social structures. The habitus is a social group's or a class's collective mode of experiencing society that is grounded in everyday life. The habitus designates the level of group organisation and experience at the group level that mediates between the individual and society (Fuchs 2003). On the one hand, humans are organised in social groups, in which they play various roles. On the other hand, they through the distribution of economic, political and cultural capital form groups "without them knowing" that have a specific likelihood of sharing certain lifestyles, preferences, tastes, habits, activities, morals, worldviews, choices, etc. "The habitus is not only a structuring structure, which organizes practices and the perception of practices, but also a structured structure: the principle of division into logical classes which organizes the perception of the social world is itself the product of internalization of the division into social classes. [...] The habitus is necessity internalized and converted into a disposition that generates meaningful practices and meaning-giving perceptions" (Bourdieu $1984,170)$. The distribution of capital characteristic for a social group, class, or class fraction is associated with "a certain life-style, through the mediation of the habitus" (Bourdieu 1984, 250).

Holzer stresses that structures of alienation and appropriation shape the experiences and life-styles of individuals and the social groups they belong to. These experiences do not determine, but in complex manners condition humans' expectations and media practices. Holzer argues that in a capitalist society, tabloid media and the media design principles of personalisation, individualisation, and scandalisation emerge from the capitalist structure of the media. It is not determined, but needs to be empirically studied how audiences react to such contents. What is for certain is that capitalist and dominative media will again and again try to manipulate audiences in favour of dominant ideologies. The point then is that social struggles should always bear in mind the role of capitalist and other one-dimensional media when aiming at a transformation of society. The emancipatory transformation of society must entail the emancipation from capitalist and dominative communication systems and practices.

Horst Holzer's Marxist theory of communication is today widely forgotten and undiscovered. Since the new crisis of capitalism started in 2008, the interest in Marx's works and Marxist theory has significantly increased. There is a diverse and rich history of Marxist theory. The advantage of the Marxist approach is that it situates the studied phenomenon, in our case communication, in society's totality, structures of 
domination, ideologies, its contradictions, dynamics, crises, social struggles, and potential alternatives. Scholars, who define themselves as critical theorists, today often extensively use non-Marxist and bourgeois theories and approaches and forget about Marxist theory's rich and diverse tradition. To render the forgotten and neglected approaches visible must entail a focus on the Marxist tradition, its representatives, approaches, categories, theories, ontologies, epistemology, ethics, politics, etc.

Today, we can often find the argument that understanding new developments (such as big data, the Internet of things, cloud computing, industry 4.0, labour 4.0, etc.) requires completely new approaches. New technologies, however, develop in the context of the capitalist world system. Marxist theory enables a critical dialectical analysis of continuities and discontinuities, the continuities of discontinuities as well as the discontinuities of continuities. Any new phenomenon, including new communication phenomena, therefore requires us to adapt theoretical categories and to assess what its continuities and discontinuities are. Marx and the Marxist tradition offer a wide set of theoretical categories - such as species-being, social being, alienation, class, commodity, surplus-value, capital(ism), means of communication, general intellect, collective worker, the state, ideology, fetishism, class struggle, praxis, socialism, communism, etc. - for the critical understanding of society, including its communicative dimension (Fuchs 2016c).

A methodological point for developing critical communication theory today is that we should not be blinded by the quest for the new, but rather discover the forgotten, hidden, marginalised dimensions and strengths of the Marxist theory tradition. Putting forgotten Marxist approaches on today's agenda by rendering them visible and adapting them in a dialectical way to our contemporary societal situation is an important contribution to the project of Marxist media and communication studies.

\section{The Reception of Horst Holzer's Works}

The reception of Holzer's works in the German-speaking world has on the one hand taken place in mainstream media/communication studies and on the other hand in the marginalised critical tradition of this field. I will discuss examples for both types of reception.

Scholars in German media and communication studies' mainstream have on single occasions commented on Holzer and the Marxist theory of communication that he stands for.

Martin Löffelholz $(2003,33)$, who is professor of media studies at IImenau Technical University, characterises materialist media studies as one of eight theoretical frameworks of journalism research. He argues that the materialist approach has low theoretical complexity and that empirical journalism research has very little to gain from it. Löffelholz claims that Marxist media/communication theory is economic reductionist and therefore limited. "The approach's economism, but also its ideological direction have reduced its theoretical complexity as well as its empirical relevance. At the start of the $21^{\text {st }}$ century, the academic debate is hardly oriented on this concept" 21 (Löffelholz 2003, 34). Heinz Pürer, who is professor emeritus of communication studies at the Ludwig Maximilian University of Munich, in his German introduction to media and communication studies refers to Löffelholz for arguing that the materialist

\footnotetext{
${ }^{21}$ Translation from German: „Dieser Ökonomismus, aber auch die ideologische Zurichtung des Ansatzes haben seine theoretische Komplexität wie seine empirische Relevanz gemindert. Am Beginn des 21. Jahrhunderts orientiert sich die wissenschaftliche Debatte kaum noch an diesem Konzept".
} 
communication theory, as represented by Horst Holzer, Wulf D. Hund and Bärbel Kirchhoff-Hund, today not even has a niche existence: Its "empirical gain and complexity are assessed as small because of its economistic and ideological orientation"22 (Pürer 2014, 169).

Klaus Merten (2007), who is professor emeritus of empirical communication research at Münster University, in his German introduction to communication studies argues that materialist media theories, as for example represented by the approaches of Holzer, Hund, Dröge or Haug, are one-dimensional: "It stands out that the materialist approach presents itself from an academic perspective very onedimensionally: Analyses and statements of the theoretical forefather Karl Marx are adopted in an uncritical and inconsiderate manner and are applied to the presence untested, although materialist analysis would require that Marx's analyses should be related to their historical situation"23 (Merten 2007, 168).

Emil Dovifat and Jürgen Wilke ${ }^{24}$ (1992) write that Karl Marx and Ferdinand Lassalle's argument that there is a contradiction between the media's commercial and informative roles has influenced left-wing critiques of capitalist media in Germany. Explicitly mentioning Franz Dröge, Horst Holzer and Dieter Prokop, the two authors claim that such left-wing scholars "with their critique at the same time question the economic and journalistic factors of the free order of society guaranteed by the Basic Law" (Dovifat and Wilke 1992, 182) ${ }^{25}$.

Taken together, these arguments make three claims about Horst Holzer's works and Marxist media/communication research in general, namely that Marxist analyses of communication are a form of economic reductionism, use Marx's allegedly outdated theory and advance anti-democratic views. These claims reflect some of the most common prejudices about Marx's theory in general (Eagleton 2011). It is furthermore striking that such criticisms tend not to engage in detail with the analyses of Holzer and other Marxists, but make sweeping judgements based on superficial readings. It looks like the labels "Communism", "Socialism" and "Marxism" have kept certain scholars from taking a closer look at the substance of theoretical arguments.

In respect to the first claim, it needs to be stressed that a purely economic analysis of capitalist media foregrounds the role of the media in respect to advertising and capital accumulation. Holzer in contrast to such an approach also stresses aspects of ideology, the state, alternative media, and alternative interpretations of media content. For Holzer, the economic dimension of the media is that it is a realm of production. He, however, in the context of communications not just stresses the production of advertisements and profits, but also the production of ideologies, legitimation, hegemony, alternatives and resistance. The media's production foundation constitutes

\footnotetext{
${ }^{22}$ Translation from German: „empirischer Ertrag und Komplexität aufgrund der ökonomistischen und ideologischen Ausrichtung als gering eingeschätzt werden“.

${ }^{23}$ Translation from German: „Es fällt auf, dass der materialistische Ansatz sich - wissenschaftlich gesehen - sehr einseitig präsentiert: Analysen und Feststellungen des theoretischen Anherrn Karl Marx werden kritik- und bedenkenlos übernommen und ungeprüft auf die Gegenwart bezogen, obwohl doch gerade materialistische Analyse fordern müsste, dass Marx's Analysen auf ihre historische Situation bezogen sein sollten"

${ }^{24}$ Dovifat contributed to the formation of media and communication studies in Germany. Jürgen Wilke is professor emeritus of media and communication studies at the Johannes Gutenberg University Mainz.

${ }^{25}$ Translation from German: „[...] stellen mit ihrer Kritik aber vielfach zugleich konstitutive wirtschaftliche und publizistische Faktoren einer vom Grundgesetz garantierten freien Gesellschaftsordnung in Frage".
} 
at the same time economic and non-economic aspects of communication. There is a dialectic of the economic and the non-economic dimension of communication (Fuchs 2016a, 2015).

The second claim relates to the question of how topical Karl Marx's theory is today. Marx's Capital is a general theory and critique of capitalism (see Fuchs 2016c for a detailed discussion). Furthermore, Marx was a dialectical thinker, which means that his approach invites us to conceive of the Marxian categories as dynamic, i.e. based on a dialectic of continuity and discontinuity. We still live in a capitalist society today, but capitalism has on a certain level of organisation changed into digital capitalism, communicative capitalism, financial capitalism, neoliberal capitalism, new imperialistic capitalism, etc.

Marx $(1867,125)$ stresses that commodities created by human labour are capitalism's "elementary form". Holzer and other Marxist communication scholars show how the commodity in the realm of communications takes on various forms that have emergent qualities. They build on Marx's general analysis of capitalism and apply it to communications in $20^{\text {th }}$ and $21^{\text {st }}$ century capitalism. Epistemologically and methodologically they employ the dialectical Marxian method of advancing from the abstract to the concrete (Marx 1857/1858, 100-108).

The third claim raises the question if Marx and Marxist theory are associated with authoritarianisms such as Stalinism and Maoism. Marx did not live at the time of Stalin and Mao, so cannot be blamed for their use of some of his vocabulary for advancing authoritarian state-capitalist systems (James 2013). In respect to Dovifat and Jürgen Wilke's claim it must be said that the Basic Law for the Federal Republic of Germany does not define advertising and for-profit media operations as aspects of a free order. Holzer $(1971,53)$ argues in this context that entertainment and advertising are excluded from the freedom of expression as defined in the German Basic Law's article five. Rather, the Basic Law defines the right to free development of human personality $(\S 2)$, the right to life and physical integrity $(\S 2)$, equality before the law $(\S 3)$, the freedom of faith and conscience (§4), the freedom of expression, arts and sciences (§5), the freedom of assembly (§8), the freedom of association (§9), the privacy of correspondence, posts and telecommunications $(\S 10)$, the freedom of movement (§11), occupational freedom (§12), the inviolability of the home $(\S 13)$, the guarantee of property that entails obligations and shall serve the public good $(\S 14)$, the right of asylum ( $\$ 16 a)$, the right of petition ( $\$ 17)$, etc. as constitutive aspects of a free order.

Holzer (1971) points out a contradiction between the basic rights defined in the German constitution and the power that capitalism gives to the opinions and economic power of the few (including capitalist media corporations). He analyses the communicative dimension of the relationship between democracy and capitalism and the role that capitalist media, media monopoly capital, media concentration, advertising, ideology, and entertainment play in this contradiction. The analysis of such a negative dialectic does not argue for the limitation of freedom, but makes an argument for the full practical realisation of basic rights. Wolfgang Abendroth (1966, 1968, 1975), the German political and legal theorist who supervised Jürgen Habermas' habilitation thesis The Structural Transformation of the Public Sphere, points in this context out that the German constitution stresses the principle of the social state in articles 20(1) and 28(1), enables the socialisation of means of production, land and natural resources in article 15, and exempts article 20 from changes in article 79 (3). Abendroth argues that there are constitutional social rights that call for the supplementation of the political democracy by a social democracy, that democratic social- 
ism can be defined as a free order based on the German constitution, and that social justice is a key condition for the guarantee of freedom. For Abendroth, the Basic Law covers the transformation of Germany into a socialist democracy (see also Holzer 1971, 43-44). "The principle of the democratic and social state governed by the rule of law is in fact based on the assumption that the principle of equality in article 3 and the idea of self-government can be transferred from the political order to the cultural and economic dimension of society [...] One has to stress that although the Basic Law has kept the late-capitalist economic system, its social antagonisms and political threats with few changes in place, it guarantees the possibilities that the majority of the legislative power that the voters elect can transform this system with legal means and without a change of the Basic Law into a socialist order. This possibility of democratising the social order by a transition to socialism cannot be removed legally by changing the Basic Law, but rather only illegally, because the legal principle of the 'democratic and social federal state' (\$20 [1]) is protected against constitutional changes (§79 [3])" (Abendroth 1966, 67, 69) ${ }^{26}$.

In respect to the media, communicative democratic socialism that stands in line with the constitutional principles of the German Basic Law does not mean state control of the media, but the existence of independent public service media and a nonprofit media sector run in the form of self-managed media organisations. These two forms are alternatives to the capitalist organisations of communicative capitalism.

The discussion shows that the dominant interpretation of Holzer's works in the German-speaking world has been superficial and political-ideologically biased by anti-Marxism and anti-socialism.

Andreas Scheu (2012) provides a Bourdieuan historical analysis of Marxist communication research's failure in West Germany. He advances a multi-factor explanation, in which political repression is just one of many factors. "Such a critique of the critical-materialist perspective is spot on. Orthodox representatives of the criticalmaterialist theory seem at least in the early phase of the 1970 s to have used empirical research merely for the exemplification of theory. Causes and causal relations between society, journalism and population are postulated theoretically and monocausally reduced to economic structures without real methodological testing [...] Such a critique of critical-materialist actors' works from the perspective of empirical social research reflects in a way these actors' distanciation from empirical social research"27 (Scheu 2016, 380). In respect to Holzer, Scheu (2012, 149-173) certainly

${ }^{26}$ Translation from German: „Das Prinzip des demokratischen und sozialen Rechtsstaats geht vielmehr davon aus, daß der Gleichheitsgrundsatz des Art. 3 und der Selbstverwaltungsgedanke sich aus der politischen Ordnung in die Kultur- und Wirtschaftsgesellschaft übertragen kann [...] So bleibt daran festzuhalten, daß das Grundgesetz zwar das spätkapitalistische Wirtschaftssystem und seine sozialen Widersprüche und politischen Gefahren mit wenigen Veränderungen bestehen gelassen hat, aber die Chance garantiert, es mit gesetzlichen Mitteln und ohne Grundgesetzänderung durch Entscheidung der Majorität der Legislative, die durch die Wähler erzwungen werden kann, in eine sozialistische Ordnung zu verwandeln. Diese Chance zur Demokratisierung der Sozialordnung durch Übergang zum Sozialismus kann nur illegal, nicht aber durch Änderung des Grundgesetzes in legaler Form, beseitigt werden, weil der Rechtsgrundsatz des ,demokratischen und sozialen Bundesstaates' (Art. 20 Abs. 1) gegen Verfassungsänderungen geschützt ist" (Art. 79 Abs. 3).

27 Translation from German: „Diese Kritik der kritisch-materialistischen Perspektive ist treffend. Tatsächlich scheinen gerade orthodoxe Vertreter der kritisch-materialistischen Theorie - zumindest was die frühe Phase in den 1970er Jahren betrifft - Empirie lediglich zur Exemplifikation der Theorie zu gebrauchen. So werden Wirkungen und Kausalzusammenhänge zwischen den Ebenen Gesellschaft, Journalismus und Bevölkerung theoretisch postu- 
stresses the negative role the professional ban played, but also focuses his analysis to a significant degree on stressing that Holzer never applied to communication studies professorships, that his critical theory focus was seen as "worthless" cultural and academic Bourdieuan capital in communication studies, that as introverted person he allegedly had a low level of Bourdieuan social capital, and that he distanced himself from neo-positivism. In respect to empirical research, Scheu argues that "it may well be due to the quality of Dröge and Holzer's empirical research that they could not accumulate capital in this realm [of academic capital]" ${ }^{28}$ (289). Scheu claims that Holzer and Dröge used complex language in order to cover up alleged weaknesses of their works (290). He concludes in his study that political reasons played a role in the displacement of the critical perspective in German media and communication studies, but that on the other hand the lack of academic, social and cultural capital resulted in the "failure of 'critical' actors" ${ }^{29}$ (295).

The problem of the analytical approach taken in Scheu's analysis is that a multifactor analysis only postulates different influencing factors, but does not discuss their relative influence on overall developments. Research requires time and space. In capitalist societies, academic time and space are mediated by the money form, which means that academic wage-labour is an important foundation of the institutionalised time and space that is necessary for conducting research, supervising PhD students, developing academic reputation, organising, attending and presenting at conferences in order to build and maintain academic networks, etc. In the case of Horst Holzer, the professional ban destroyed the institutional foundation of his influence. It was therefore much more difficult for him than for others to gain attention and influence. Scheu's analysis somewhat overlooks how in the case of critical communication studies in Germany, various political factors negatively affected economic and institutional possibilities and therefore marginalised and repressed critical actors and positions. The danger of such an analysis is that it reduces complex conditions shaped by various forms of inner-academic and external political repression to issues of individual failures and individual responsibility. In a capitalist society, the access to economic resources (including money, wage-labour, space, time) is a key enabling factor for the professional development of professional reputation, professional networks, the practicing and development of skills, institutional influence and decision-making, etc. Access to economic resources is not a determining, but important conditioning, i.e. enabling and constraining factor. If the access to economic resources is limited (e.g. by political and ideological repression), then the development of political, social and cultural aspects of life is made more difficult. Scheu's analysis has certainly been interpreted in a way that foregrounds individual failures and responsibility (see Pürer 2014, 48; Pürer 2015, 5).

\footnotetext{
liert und monokausal auf ökonomische Strukturen zurückgeführt, ohne tatsächlich methodisch getestet zu werden. [...] Eine solche Kritik an den Arbeiten kritisch-materialistischer Akteure aus einer empirisch-sozialwissenschaftlichen Perspektive heraus spiegelt in gewisser Weise die weiter oben dargestellte Distanzierung der Akteure von der empirischsozialwissenschaftlichen Forschung".

${ }^{28}$ Translation from German: „Es mag also durchaus auch an der Qualität der empirischen Arbeiten von Dröge und Holzer gelegen haben, dass sie in diesem Bereich kein Kapital akkumulieren konnten“.

${ }^{29}$ Translation from German: „Aus dieser Perspektive betrachtet, erscheint die Geschichte einer ,Kritischen Kommunikationsforschung' in den 1970er- und 1980er-Jahren auch als Geschichte eines Scheiterns ,kritischer' Akteure“.
} 
Among critical media scholars active in the German-speaking world, Holzer's reception has been undertaken in a much more thorough and positive manner than in the field's mainstream. I will discuss three examples.

Franz Dröge (2002), who with works such as Wissen ohne Bewußtsein (Knowledge Without Consciousness, Dröge 1972) made important contributions to Marxist communication theory in Germany, contributed an entry about Holzer's book Gescheiterte Aufklärung? [Failed Enlightenment?] to a book that presents 200 key works for communication studies. Dröge argues that Holzer's works have been ignored in media and communication studies and were much more influential in sociology, philosophy, and political science. Dröge stresses that Holzer's empirical analysis shows how Germany's media systems is democratically insufficient.

Manfred Knoche $(2001,185)$, who has consistently practiced the critique of the political economy of media/communication (see Knoche 2016), refers to Holzer's roles of the media and discerns between the media's economic roles, its ideological role, and its role in the reproduction of labour-power. Knoche (2002) distinguishes four roles of the media in capitalism: 1 . media capital accumulation, 2 . advertising, 3 . the guarantee of legitimation and domination, 4. the reproduction and qualification of labour-power.

Sebastian Sevignani $(2016,4-5)$ argues that in the German-speaking world, Horst Holzer and Manfred Knoche have contributed to grounding and systematising the critique of the media's political economy. Sevignani characterises Holzer's approach as a combination of critical political economy and social psychology (5). He argues that media and communication play a role in the organisation and automation of production, communicative labour, the circulation and advertising of commodities, the reproduction and (de-)qualification of labour-power, the circulation of ideologies, alternative media, and contradictory media reception. The analysis of digital capitalism based on Marxist theory shows according to Sevignani that Marxian analysis' "liveliness and usefulness for understanding contemporary transformation processes of society without having, also due to academic and inner-disciplinary marginalisation tendencies, fully utilised its theoretical and practical potential"30 (Sevignani 2016, 20).

A wealth of insights can be gained from the discovery of the Marxist theory for a critical theory and analysis of media and communication. The reception history of Horst Holzer's works is an example that shows how political repression and ideologically motivated biases result in silences, superficiality, one-dimensionality, and distortion. tripleC's translation of Horst Holzer's article aims to contribute to a better and fuller understanding of the German approach to the critique of the political economy of media/communication.

\section{References}

Abendroth, Wolfgang. 1975. Arbeiterklasse, Staat und Verfassung: Materialien zur Verfassungsgeschichte und Verfassungstheorie der Bundesrepublik. Frankfurt am Main: Europäische Verlagsanstalt.

\footnotetext{
30 Translation from German: „Der an die Arbeiten von Karl Marx und deren vielfältigen Weiterentwicklungen anknüpfende Ansatz der KPOeMK kann so eindrucksvoll seine Lebendigkeit und Nützlichkeit auch zum Verständnis aktueller gesellschaftlicher Transformationsprozesse unter Beweis stellen, ohne dabei, auch aufgrund von akademischen und innerdisziplinären Marginalisierungstendenzen, sein theoretisches und praktisches Potenzial bisher voll ausgeschöpft zu haben“.
} 
Abendroth, Wolfgang. 1968. Begriff des demokratischen und sozialen Rechtsstaates im Grundgesetz der Bundesrepublik Deutschland. In Rechtsstaatlichkeit und Sozialstaatlichkeit. Aufsätze und Essays, ed. Ernst Forsthoff, 114-144. Darmstadt: Wissenschaftliche Buchgesellschaft.

Abendroth, Wolfgang. 1966. Das Grundgesetz. Pfullingen: Neske.

Bönkost, Jan. 2011. Im Schatten des Aufbruchs. Das erste Berufsverbot für Horst Holzer und die Uni Bremen. Grundrisse 39: 29-37.

Bourdieu, Pierre. 1984. Distinction: A Social Critique of the Judgement of Taste. London: Routledge.

Brecht, Bertolt. 1932/2000. The Radio As An Apparatus of Communications. In Brecht On Film \& Radio, ed. Marc Silberman, 41-46. London: Methuen.

Dovifat, Emil and Jürgen Wilke. 1992. Zeitungslehre. Band 2: Redaktion - Die Sparten; Verlag und Vertrieb, Wirtschaft und Technik - Sicherung der öffentlichen Aufgabe. Berlin: de Gruyter.

Dröge, Franz. 2002. Horst Holzer: Gescheiterte Aufklärung? Politik, Ökonomie und Kommunikation in der Bundesrepublik Deutschland In Schlüsselwerke für die Kommunikationswissenschaft, ed. Christina Holtz-Bacha and Arnulf Kutsch, 206-208. Wiesbaden: Westdeutscher Verlag.

Dröge, Franz. 1972. Wissen ohne Bewußtsein: Materialien zur Medienanalyse der Bundesrepublik Deutschland. Frankfurt am Main: Athenäum Fischer.

Eagleton, Terry. 2011. Why Marx Was Right. New Haven, CT: Yale University Press.

Fuchs, Christian. Forthcoming (accepted for publication). Raymond Williams' Communicative Materialism. European Journal of Cultural Studies

Fuchs, Christian. 2017. Social Media: A Critical Introduction. London: Sage. 2nd edition.

Fuchs, Christian. 2016a. Critical Theory of Communication. New Readings of Lukács, Adorno, Marcuse, Honneth and Habermas in the Age of the Internet. London: University of Westminster Press.

Fuchs, Christian. 2016b. Henryk Grossmann 2.0: A Critique of Paul Mason's Book "PostCapitalism: A Guide to Our Future". tripleC: Communication, Capitalism \& Critique 14 (1): 232-243.

Fuchs, Christian. 2016c. Reading Marx in the Information Age. A Media and Communication Studies Perspective on "Capital Volume I". New York: Routledge.

Fuchs, Christian. 2015. Culture and Economy in the Age of Social Media. New York: Routledge.

Fuchs, Christian. 2011. Foundations of Critical Media and Information Studies. London: Routledge.

Fuchs, Christian. 2008. Internet and Society: Social Theory in the Information Age. New York: Routledge.

Fuchs, Christian. 2003. Some Implications of Pierre Bourdieu's Works for a Theory of Social Self-Organization. European Journal of Social Theory 6 (4): 387-408.

Habermas, Jürgen. 1991. The Structural Transformation of the Public Sphere. An Inquiry into a Category of Bourgeois Society. Cambridge, MA: MIT Press.

Habermas, Jürgen. 1987. The Theory of Communicative action. Volume 2. Boston, MA: Beacon Press.

Habermas, Jürgen. 1984. The Theory of Communicative action. Volume 1. Boston, MA: Beacon Press.

Holzer, Horst. 1994. Medienkommunikation: Einführung in handlungs- und gesellschaftstheoretische Konzeptionen. Opladen: Westdeutscher Verlag.

Holzer, Horst. 1988. Kommunikative Rationalität als Basis der Kritik. Zur Theorie des kommunikativen Handelns von Jürgen Habermas. Deutsche Zeitschrift für Philosophie 36 (11): 989-1002.

Holzer, Horst. 1987. Kommunikation oder gesellschaftliche Arbeit? Zur Theorie des kommunikativen Handelns von Jürgen Habermas. Berlin: Akademie. 
Holzer, Horst. 1985a. The Politics of Telecommunication in the Federal Republic of Germany. Media, Culture \& Society 7 (1): 85-103.

Holzer, Horst. 1985b. Theorieprogramme und Kapitalismus: Zur Geschichte der bürgerlichen Soziologie [English translation of the title: Theory Programmes and Capitalism: On the History of Bourgeois Sociology]. Berlin: Akademie-Verlag \& Frankfurt am Main: Verlag Marxistische Blätter.

Holzer, Horst. 1983. The "Use-Value" of Social Communication and the Reality of the Media in West German Capitalism. Media, Culture \& Society 5 (1): 89-100.

Holzer, Horst. 1982. Soziologie in der BRD: Theorienchaos und Ideologieproduktion. Frankfurt am Main: Verlag Marxistische Blätter.

Holzer, Horst. 1981. Wissenschaftsfreiheit und Berufsverbot. Widerspruch 2/1981: 16-24.

Holzer, Horst. 1980. Mass Communications in the "SPD-State": Some Issues of Media Politics in the Federal Republic of Germany 1970-78. Media, Culture \& Society 2 (2): 139-150.

Holzer, Horst. 1975. Theorie des Fernsehens: Fernseh-Kommunikation in der Bundesrepublik Deutschland. Hamburg: Hoffmann und Campe.

Holzer, Horst. 1973. Kommunikationssoziologie. Reinbek bei Hamburg: Rowohlt.

Holzer, Horst. 1971. Gescheiterte Aufklärung? Politik, Ökonomie und Kommunikation in der Bundesrepublik Deutschland. München: Piper.

Holzer, Horst and Joseph Schmid. 1972. Alternativen. In Massenkommunikationsforschung 1: Produktion, ed. Dieter Prokop, 129-135. Frankfurt am Main: Suhrkamp.

James, C. L. R. 2013. State Capitalism and World Revolution. Oakland, CA: PM Press.

Knoche, Manfred. 2016. The Media Industry's Structural Transformation in Capitalism and the Role of the State: Media Economics in the Age of Digital Communications. tripleC: Communication, Capitalism \& Critique 14 (1): 18-47.

Knoche, Manfred. 2002. Kommunikationswissenchaftliche Medienökonomie als Kritik der Politischen Ökonomie der Medien. In Medienökononomie in der Kommunikationswissenschaft. Bedeutung, Grundfragen und Entwicklungsperspektiven. Manfred Knoche zum 60. Geburtstag, ed. Gabriele Siegert, 101-109. Münster: Lit.

Knoche, Manfred. 2001. Kapitalisierung der Medienindustrie aus politökonomischer Perspektive. M\&K - Medien und Kommunikationswissenschaft 49 (2): 177-194.

Kommittee für Grundrechte und Demokratie, ed. 1982. Ohne Zweifel für den Staat: Die Praxis zehn Jahre nach dem Radikalenerlaß. Hamburg: Rowohlt.

Löffelholz, Martin. 2003. Kommunikatorforschung: Journalistik. In Öffentliche Kommunikation: Handbuch Kommunikations- und Medienwissenschaft, ed. Günter Bentele, Hans-Bernd Brosius and Otfried Jarren, 28-53. Wiesbaden: Westdeutscher Verlag.

Luhmann, Niklas. 1995. Social Systems. Stanford, CA: Stanford University Press.

Marx, Karl. 1867. Capital Volume I. London: Penguin.

Marx, Karl. 1857/1858. Grundrisse. London: Penguin.

Marx, Karl. 1842. Proceedings of the Sixth Rhine Province Assembly. First Article. Debates on Freedom of the Press and Publication of the Proceedings of the Assembly of the Estates. In Marx \& Engels Collected Works Volume 1, 132-181. London: Lawrence \& Wishart.

Merten, Klaus. 2007. Einführung in die Kommunikationswissenschaft. Berlin: LIT. $3^{\text {rd }}$ edition.

Negt, Oskar and Alexander Kluge. 1993. Public Sphere and Experience: Toward an Analysis of the Bourgeois and Proletarian Public Sphere. Minneapolis, MN: University of Minnesota Press.

Pürer, Heinz. 2015. Journalismusforschung. Konstanz: UVK.

Pürer, Heinz. 2014. Publizistik- und Kommunikationswissenschaft. Konstanz: UVK. $2^{\text {nd }}$ edition.

Schamberger, Kerem. tripleC-Interview with Kerem Schamberger about Occupational Bans, Left-Wing Communication Studies and Critique of German Academia. tripleC: Commmunication, Capitalism \& Critique 15 (1): 82-90. 
Scheu, Andreas. 2016. Journalismus aus der Perspektive der Kritischen Theorie. In Handbuch Journalismustheorien, ed. Martin Löffelholz and Liane Rothenberger, 369-384. Wiesbaden: Springer VS.

Scheu, Andreas M. 2012. Adornos Erben in der Kommunikationswissenschaft. Eine Verdrängungsgeschichte? Köln: Herbert von Halem.

Sevignani, Sebastian. 2016. Kritische Politische Ökonomie. In Handbuch Medienökonomie, ed. Jan Krone and Tassilo Pellegrini. Wiesbaden: Springer VS.

Williams, Raymond. 1977. Marxism and Literature. Oxford: Oxford University Press.

\section{Bibliography of Horst Holzer's Main Works:}

Holzer, Horst. 1966. Selbstverständnis und Inhaltsstruktur aktueller Illustrierter: Dargestellt an den Zeitschriften Quick, Revue, Stern [English translation of the title: Self-Understanding and Content Structure of Contemporary Magazines: The Magazines Quick, Revue, Stern]. Dissertation, Ludwig Maximilian University of Munich, April 18, 1966. Published as book: Holzer, Horst. 1967. Illustrierte und Gesellschaft: Zum politischen Gehalt von Quick, Revue und Stern [English translation of the title: Magazines and Society: On the Political Content of Quick, Revue and Stern]. Freiburg im Breisgau: Rombach.

Holzer, Horst, ed. 1968. Facsimile-Querschnitt durch die Quick [English translation of the title: Facsimile-Cross Section of "Quick"]. München: Scherz.

Holzer, Horst. 1969. Massenkommunikation und Demokratie in der Bundesrepublik Deutschland [English translation of the title: Mass Communication and Democracy in the Federal Republic of Germany]. Opladen: Leske. Habilitation thesis.

Holzer, Horst. 1971. Gescheiterte Aufklärung? Politik, Ökonomie und Kommunikation in der Bundesrepublik Deutschland [English translation of the title: Failed Enlightenment? Politics, Economy and Communication in the Federal Republic of Germany]. München: Piper.

Holzer, Horst \& Karl Steinbacher, eds. 1972. Sprache und Gesellschaft [English translation of the title: Language and Society]. Hamburg: Hoffmann und Campe. $\left(2^{\text {nd }}\right.$ edition 1975)

Holzer, Horst. 1973. Kommunikationssoziologie [English translation of the title: Communication Sociology]. Reinbek (bei Hamburg): Rowohlt. ( $2^{\text {nd }}$ edition 1976) Spanish translation: Sociología de la comunicación, translated by José Luis Pascual Arranz (Madrid: Akal, 1978)

Holzer, Horst. 1974. Kinder und Fernsehen: Materialien zu einem öffentlichrechtlichen Dressurakt [English translation of the title: Children and Television: Materials on a Public-Service Animal Performance Act]. München: Hanser.

Holzer, Horst. 1975. Theorie des Fernsehens: Fernseh-Kommunikation in der Bundesrepublik Deutschland [English translation of the title: Television Theory: Television-Communication in the Federal Republic of Germany]. Hamburg: Hoffmann und Campe. 
Holzer, Horst. 1976. Report, Kabelfernsehen in der BRD [English translation of the title: Report: Cable Television in the Federal Republic of Germany]. Frankfurt am Main: Verlag Marxistische Blätter.

Holzer, Horst. 1977. Kapitalismus als Abstraktum? Makro-soziologische Systemtheorie in der Soziologie der USA und der BRD [English translation of the title: Capitalism as Abstraction: Macro-Sociological Systems Theory in the Sociology of the USA and the Federal Republic of Germany]. Berlin: Akademie-Verlag \& Frankfurt/Main: Verlag Marxistische Blätter (auch unter dem Titel: Gesellschaft als System: Makrosoziologische Systemtheorie in der Soziologie der USA und der BRD [also published under the title: Society as System: Macro-Sociological Systems Theory in the Sociology of the USA and the Federal Republic of Germany]).

Holzer, Horst. 1978. Evolution oder Geschichte? Einführung in Theorien gesellschaftlicher Entwicklung [English translation of the title: Evolution or History? Introduction to Theories of Society's Evolution]. Köln: Pahl-Rugenstein (1979, Berlin: AkademieVerlag)

Holzer, Horst. 1980. Medien in der BRD: Entwicklungen 1970-1980 [English translation of the title: Media in the Federal Republic of Germany: Developments 19701980]. Köln: Pahl-Rugenstein.

Holzer, Horst. 1981. Verkabelt und verkauft? Streitpunkt: Kabelfernsehen [English translation of the title: Connected and Sold Out? The Cable Television Controversy]. Frankfurt am Main: Verlag Marxistische Blätter.

Holzer, Horst. 1982. Soziologie in der BRD: Theorienchaos und Ideologieproduktion [English translation of the title: Sociology in the Federal Republic of Germany: Theory Chaos and Ideology Production]. Berlin: Akademie-Verlag \& Frankfurt am Main: Verlag Marxistische Blätter.

Betz, Klaus \& Horst Holzer, eds. 1983. Totale Bildschirmherrschaft? Staat, Kapital und "Neue Medien" [English translation of the title: Total Screen Domination? State, Capital and "New Media”]. Köln: Pahl-Rugenstein ( $2^{\text {nd }}$ edition 1984).

Holzer, Horst. 1984. Orwell \& Bundesrepublik: Erfassen, Überwachen, Manipulieren [English translation of the title: Orwell \& the Federal Republic of Germany: Collection, Surveillance, Manipulation]. Frankfurt am Main: Verlag Marxistische Blätter.

Holzer, Horst. 1985. Theorieprogramme und Kapitalismus: Zur Geschichte der bürgerlichen Soziologie [English translation of the title: Theory Programmes and Capitalism: On the History of Bourgeois Sociology]. Berlin: Akademie-Verlag \& Frankfurt am Main: Verlag Marxistische Blätter.

Holzer, Horst. 1987. Kommunikation oder gesellschaftliche Arbeit? Zur Theorie des kommunikativen Handelns von Jürgen Habermas [English translation of the title: Communication or Societal Work? On Jürgen Habermas' Theory of Communicative Action]. Berlin: Akademie-Verlag. 
Holzer, Horst. 1989. Die Privaten: Kommerz in Funk und Fernsehen [English translation of the title: The Private Ones: Commerce in Radio and Television]. Köln: PahlRugenstein.

Holzer, Horst. 1994. Medienkommunikation: Einführung in handlungs- und gesellschaftstheoretische Konzeptionen [English translation of the title: Mediated Comunication: Introduction to Concepts of Action Theory and Theories of Society]. Opladen: Westdeutscher Verlag. 


\title{
The Forgotten Marxist Theory of Communication \& Society
}

\author{
Horst Holzer
}

\section{Translated from German into English by Christian Fuchs}

There is no doubt that in the past years the representatives of a position that in the 1970s contributed intensively and systematically to the topics discussed in this article, contributed very little to the dispute about media and communication theory. I am talking about the authors, who based on different motivations and methods, dedicated themselves in the context of historical-materialist social science to the analysis of the realms of "communication" and "mass-mediated communication"31. However, it was neither disinterest nor intentional absence that resulted in the circumstance that these attempts only created a "forgotten theory" (Robes 1990) and were not capable to keep up with the discourse in media and communication theory.

One of the main reasons for this approach's vanishing into oblivion seems to be that due to the self-destruction and external destruction of "real existing socialism", there was a ban of historical materialism in general and historical-materialist communication and media theory in particular. Those, who in former times were on every occasion very vociferous about Marx, Engels, Lenin, etc., have often supported this ban.

It is evident that the available results of historical-materialist communication and media theory pose (especially in light of the deficits of the mentioned conceptions) enough "worthy" discussion material that despite the undoubtedly existing weaknesses can in no way be ignored. The following sections will illustrate these issues.

\section{Communication in Society and Societalisation (Vergesellschaftung)}

Talking about the human life form, that is societal relations and historical movements, implies starting from, as Marx and Engels $(1846,37)$ say, a premise that can be "verified in a purely empirical way": One has to first consider real, active humans in their practical relations to each other and to nature. Humans "in their actual, empirically perceptible process of development under definite conditions" (Marx and Engels $1846,43)$ are the "real premises from which abstraction can only be made in the imagination" (Marx and Engels 1846, 186). These assumptions form the core of Marx and Engels' materialism. This materialism, according to the First Thesis on Feuerbach, does not conceive "things [Gegenstand], reality, sensuousness [...] in the form of the object, or of contemplation", but rather "subjectively" as "sensuous human activity, practice" (Marx and Engels 1846, 569).

Humans express their practice, their sensuous human activity, in essence in the production process. Three mutually connected processes characterise production: the development of humans' physical, psychological and mental capacities; the production of physical and ideational means of subsistence; and the creation of living

\footnotetext{
${ }^{31}$ See also the collection of essays After the Frankfurt School that was published in Media, Culture \& Society (Hoffman et al. 1983) and featured contributions by Burkhard Hoffmann, Werner Hofman, Jörg Huffschmid, Klaus Kreimeier, Franz Dröge, Oskar Negt/Alexander Kluge, Wulf D. Hund, Wulf D. Hund/Bärbel Kirchhoff-Hund, Horst Holzer, Dieter Prokop. The following discussion refers especially to the concepts and analyses by Hoffmann, Hofman, Holzer, Huffschmid, Hund and Kirchhoff-Hund, taking into account the works by Bisky $(1976,1978,1986)$ and Robes (1990).
} 
conditions that themselves provide the social framework for the entire production process (understood in a non-economic sense).

In production, men enter into relation not only with nature. They produce only by co-operating in a certain way and mutually exchanging their activities. In order to produce, they enter into definite connections and relations with one another and only within these social connections and relations does their relation with nature, does production, take place (Marx 1849, 211).

Marx and Engels have again and again stressed the importance of this circumstance. "This social relation, production relation, appears in fact as an even more important result of the process than its material results" (Marx 1857/1858, 458). What Marx and Engels call the real production process can thus only be understood as total process developing in and as history. Also the circumstance that for Marx and Engels the crucial point of this process is the societalised human/nature-metabolism does not change this matter. In this respect the "real production process" as the realisation of all individual and collective human modes of existence constitutes an at all times societal relation, in which linguistically interacting humans communicatively and institutionally create the connections to subjective-expressive, practical-moral and cognitive, technological-organisational action. The connections themselves are mediated with each other and have become disembedded during the course of history. They differentiate themselves from the societal production relations as well as from the embedded societal relations that themselves are based on the realisation of exactly these connections.

Based on this axiom, historical-materialist communication and media theory is based on the insight that the foundation of any organisation of life in society is the manner in which humans secure on a particular stage of their historical development their existence and the evolvement of their subjective qualities and social relations. The central topics in historical-materialist argumentations are therefore the concretesocietal, historically changing relations, in which humans ensure their existence and life and politically, legally and culturally reflect and articulate their individual and collective situations that they solidify in institutional-organisational constructions and arrangements (Laclau and Mouffe 2001) ${ }^{32}$.

A fundamental implication of the historical-materialist approach is that concretesocietal relations are at the same time understood as result and premise of the sketched activities. It comes as no surprise that in light of such a background, for example Luhmann's autopoietic understanding of society and the (societal) individual faces reservations. In the approach that I advance, there is no place for the hypothesis that society can be reduced to self-(re)producing communication and individuals to self-(re)producing cognitive and cellular processes. The logic of autopoiesis neither understands humans as "individuals active in society" nor the societal process as "the productive appropriation, change and reshaping of the world" (Mocek 1991, 279-280).

We analyse the realm of communication in society as a complex that as a moment of a particular societal formation is profoundly shaped by relations of production, reflection and institutionalisation that are to be understood in such a manner. This

\footnotetext{
32 "Reflection" here means "processing" and not "mirroring". "Articulation" is understood in the sense of Laclau/Mouffe as "discursive connection" of political, cultural, legal arguments in "popular discourse".
} 
means that the historical-materialist theory of communication and the media is not primarily interested in "the communication process' universals" and thereby also not in the physical elements of human communication, such as thinking and speaking, that are valid under all possible societal conditions (Hund and Kirchhoff-Hund 1980, 93). The interest lies much more in analysing the communication process - the entire (linguistically organised) process of the production, distribution, interaction, understanding, and use of information (quite in Luhmann's sense) - in its specific societal form determination.

Because the entanglement of the relations of production, reflection and institutionalisation creates the specifically societal form, in which humans accomplish securing their existence and developing their possibilities, the realisation of human life with necessity takes place as communicative action. Communicative action is indeed the result of the process through which the "specifically human form of the reproduction of life" has taken on the form of the societal production of the living conditions (Habermas 1976, 149). At the same time, communicative action is obviously a moment that in the context of "linguistically generated intersubjectivity" (Habermas 1987, 385) is always constitutive of this form of reproduction. In this respect, a societal collective's communication structures do not just express its degree of societalisation. Communication structures that manifest themselves in the interactive contexts of the collective and in the "higher level" of (whatever kind) of "public" also (co-)produce this degree (Habermas 1987). Societal communication that likewise refers to interindividual relations and totalities, can be characterised in a threefold manner:

1. Communication is medium and co-supporter of the physical and symbolic, practical and theoretical appropriation of nature and social practice;

2. Communication is simultaneously the result and the constituting and mediating factor of human activities that create the conditions for societal and individual life;

3. Communication is a means that on the one hand guarantees and on the other hand (co-)produces the development, socialisation and practicing of forms of needs, thoughts and activities that are realised at the societal and the individual level.

Such abstract notes of course merely conceive of communication as general societal fact and say nothing about particular, real historical, concrete-societal modes of communication. Nevertheless such abstract arguments pose the opportunity to ask questions about any historical-concrete form of interaction-oriented or public communication, including mass communication, that practices such publicly oriented communication by technological mass media:

1. How is mass communication arranged as a specific form of public communication? How can communication be described as moment of the societal relation whose result and co-shaping factor it is?

2. How does mass communication fulfil the communicative functions sketched out above? What contribution does communication make to the formation of individual and collective consciousness?

A closer analysis of the presented arguments shows that there are at least two "blind spots" (Robes 1990, 85). The first one concerns the discussion of the relation between language and communication. There are indeed a couple of approaches on this issue. The starting point is the classical aphorism: 
Language is as old as consciousness, language is practical, real consciousness that exists for other men as well, and only therefore does it also exist for me; language, like consciousness, only arises from the need, the necessity of intercourse with other men (Marx and Engels 1846, 49).

This aphorism resulted in the hypothesis that

communication is not an isolated activity, but an activity that is normally surrounded by a plurality of non-linguistic processes that are directly important for securing the success of linguistic understanding (Vieweger 1983, 277; see also Autorenkollektiv 1974, Erckenbrecht 1973, Hund 1976).

The treatment of this topic has not been consequently continued in historicalmaterialist analysis (an exception is Krüger 1986). Especially missing has been a systematic engagement with newer concepts from speech act theory, communication theories and discourse theories that have for example been advanced by Habermas and others (Habermas 1988, Habermas 1993, Böke 1993). Confronting such concepts could without a doubt in a very targeted manner engage with the problem that is still unsolved in the historical-materialist approach. This problem concerns on the one hand the mediation of communication and its "linguistic conditions of possibility" (Habermas 1987, 380) and on the other hand what was further above described as "production by social individuals" (Marx 1857/1858, 85).

The second "blind spot" concerns the question how one should conceive of the relation between linguistically mediated, intersubjective communication and the mode of communication that is an interactive, societal complex that encroaches intersubjective communication. The historical-materialist argumentation is oriented on the axiom that social action constitutes the reflexively determined, practice-bounded production and handling of social reality and that this reality is simultaneously the relatively independent form that moves "stubborn" (and is often opposed to action) and in which action unfolds. But thus far there has been no comprehensive approach trying to work out the relationship of language, communication and modes of communication, including the genesis and the particular "emergent" qualities of the latter. This theoretical deficit entails that also the historical development of the modes of communication has not been systematically studied and has not been set in relation to specific forms of society (compare Habermas', Luhmann's and Marx's concepts of the sequence of societal formations - Jürgens 1985).

Historical-materialist sociology has had an enduring focus on the relationship between the form of society and its characteristic mode of communication that articulates itself in capitalism's history. Capitalist communication is the empirical starting point of the historical-materialist analysis of public communication in society (Holzer 1990b).

\section{The Initial Empirical Problem: The Transformation of Societal Communication into Capitalist Media's Communication}

The historical-materialist theory of communication and the media starts with the assumption that public communication that is practiced in religious, artistic, academic, economic and administrative institutions, was in the pre-capitalist era obviously accomplished with the help of language and writing. Neither slave holding societies nor feudal societies used additional media for the diffusion of communication (although 
such media were technologically possible; think for example of woodcut printing or the metal letterpress in $8^{\text {th }}$ and $14^{\text {th }}$ century China).

The establishment of merchant capitalism in the $17^{\text {th }}$ century created an impulse for the development of a mode of communication, in which the mass distribution of information could be achieved with the help of a new medium. Merchant capitalists act based on the principle of selling commodities in order to achieve a surplus. As a consequence, their economic existence depends on calculable information about market processes, movements of supply and demand, changes and differentiations of prices. Merchant profit originates mainly from the price differences on markets. Large trading houses organised the activities of trade writers in order to obtain such market data. Such writers collected market information that the client received by letter as a non-public notice. Gutenberg's metal letterpress enabled trade writers to produce more extensive papers that besides market information also contained information about foreign countries and people and their cultural, political and economic forms of life. Gradually such bulletins became distributed as independent pamphlets that were suited for a broader public. But there were decisive limits to the public mass distribution of such news: First, there was a lack of interest in non-public information that only served the instrumental interests of merchant capitalists and the aristocratic, clerical and academic establishment. Second, there were the absolutist state's and the Church's measures of censorship and control. Third, the large majority of the population only had a low level of education.

Industrial capitalism further advanced the development of the means of communication. Not least the use of public communication media in the French Revolution supported this development. Industrial capitalism is in contrast to merchant capitalism a producing economic system that is based on the economic exploitation of wage-labour. It does not generate profit by buying and selling, but by the production of commodities. This process works in such a way that the labour-power that depends on and that is put to work by capital produces more than it costs for the capitalists. The working day is split into the necessary labour time that reproduces labourpower and surplus labour time that capitalists consume as a gratis resource. For the realisation of the surplus value contained in commodities, it is decisive that the products are sold on the market. In order to do so, capitalists need to systematically organise commodity sales. For this purpose, they especially use fast and cost-efficient means of communication that guarantee the transport of commodities (railway, steamships), news (telegraph) and advertisements that describe commodities (newspapers).

The expansion of means of communication that because of their reach and the mass distribution they enabled were used for the effective announcement of products and services, evidently expressed itself with the establishment of the bourgeois class in the continuous growth of newspaper- and magazine-production. This circumstance shows that there is not just a capitalist interest in the production of newspapers and magazines as medium for advertising commodities, but also a capitalist interest in the profitable investment of capital in the media industry. In Germany, the combination of economic and ideological resulted at the end of the $19^{\text {th }}$ century in the first stage of institutions of mass communication: The industrial media sector that was based on Koenig \& Bauer's rotary printing technology emerged. It was at the same time a profitable sphere of investment for productive capital, an advertising forum, and a power providing ideological support for the ruling class.

This development took place exactly at the time when capitalism entered into its monopolistic and imperialist phase and domestic political relations between capital 
and labour became more and more exposed to the actions of workers and employees organised in trade unions and political parties. The virulent capital-economic and capital-ideological aims of the bourgeois class, and especially of its dominant fractions, have decisively shaped the vigorous advancement of newspapers and magazines' production and distribution:

1. The bourgeoisie is interested in a market (such as the press market with its mass audience) that can likewise be used as realm for sales and advertising;

2. The bourgeoisie hopes to have a medium that serves to create understanding among the bourgeois fractions and propagates the capitalist form of society and life as well as the struggle against any type of critique of capitalism.

Developments similar to the historical origin of the press could also be observed in respect to radio and television. On the one hand, the market and production interests of capital-intensive electronic and chemical corporations controlled broadcasting's technological development. On the other hand, broadcast corporations use the produced technology for its production and advertising purposes and public service institutions use the same technology as a means for societal integration. The use of the press and broadcasting as instruments for capitalist domination and state domination does of course not rule out attempts by trade unions and parties to use the media for their aims.

After the Nazis' perverse use of the media as means of drill and oppression had come to an end, the sector of mass communication in Germany started to expand at the levels of the industrial economy and the state. A societal complex emerged that exports its products - hardware and software in sectors such as the press, radio, television, film, video, sound recording, computing, posters - even to the most distant national and international corners. This complex's quality can be observed both in mediated communication's economic functions and its political "trademarks". By the latter we mean the power structure characteristic for the capitalist state that forms the context, in which mediated communication's constitution, relevance and effects take place and that thereby decides what sort of character the realisation of the freedom of information, opinion and publishing takes on.

Mediated communication's organisation and functionality takes place under the conditions of capitalist society. The concrete form of mediated communication therefore depends on the constellation of social relations that these conditions produce. The capitalist constellation is characterised by an antagonism that shapes society and that results with necessity from the dominative relationship between capital on the one side and human labour-power and life quality on the other side. There is an antagonism between on the one side industrial and finance capital's economic and state-political "bearers of responsibility", who make up the core of the decisive "veto groups" in society, and on the other side the mass of humans, who for the most part directly depend on capital and possess nothing more than their labour-power, their votes and possibly their political initiative.

The concrete quality of factually realised mediated communication depends on this antagonistic relation's status in three respects:

1. It plays a role if and to what extent mediated communication makes an appearance as economic and political domination. 
2. It plays a role if and to what extent the fundamental right to freedom of information and opinion can be asserted against the capitalist and state-dominative control of mediated communication.

3. It plays a role if and to what extent forms of mediated communication can be realised that represent the emancipatory interests of the majority of the population and are oriented against the dependence on capital and the state.

The economically and politically motivated internationalisation of media systems in capitalism makes evident that the discussed characteristics of mediated communication are not only shaped by national conditions.

\section{The Central Analytical Topics: The Political Economy of the Media and the Social Psychology of Media Audiences}

Our short sketch of the empirical problems from which the historical-materialist approach starts in its conceptualisation of mediated communication, outlines the central fields of analysis (Robes 1990):

- The relationship of the economy, the state and mediated communication;

- The media's forms of organisation and functional spheres;

- The audience's everyday practices and the use-values it demands from the media and media contents.

\subsection{Economy, State, Mediated Communication}

The itemisation of "economy, state, mediated communication" is based on the assumption that "the central precondition for the existence of capitalist society is connected to the economic system's conditions of and needs for reproduction" (Graf 1993, 97-98). It must therefore be our first task to describe the current form of this system that is based on the private production of goods and services by waged and salaried labour. The following topics are relevant in this context: the high monopolisation of the conditions of production and circulation, the establishment of internationally intertwined capital centres that dominate markets, and the constant destruction of non-monopolist companies. We must in this context especially stress three circumstances:

1. The continuous scientific and technological progress and the associated rationalisation of production, organisation and jobs;

2. The chronic low degree of capacity utilisation, the continuous decrease of purchasing power and demand, and millions of unemployed persons;

3. The problem that the foreign expansion of capital faces limits, for example in respect to obtaining state subsidies.

My hypothesis is that the capitalist economy in general and the sketched contemporary economy cannot alone create and maintain their conditions and preconditions (Esser 1985). The capitalist economy requires extra-economic safeguards put into place by the state (Graf 1993, 99-100):

1. It requires a constitutional state that guarantees the formal-juridical forms of ownership and intercourse as well as private property owners' legal freedom and equality (in respect to the control of the means of production, the "ownership" of labour-power, etc.). 
2. It requires an interventionist state that guarantees the fundamental physical preconditions of the economy's infrastructure, economic policies' ring capacities, the support of unprofitable industries, the protection of national markets from international competition, and the rectification of the economic circuit's negative consequences.

3. It requires a welfare state that guarantees the reproduction of workers whose survival depends on wages and salaries as well as their political-ideological integration.

Given such a field of duty, the state has developed into a differentiated network of instances and apparatuses. But these institutions' "corridor of political action" is fairly restricted (Hoffmann 1987, 344) because the state can only indirectly, mediated by money and the law, relate to the economy. It must also strictly respect the "inviolability" of capitalism's economic principle. In addition, the internationalisation of the movement of capital and finance has restricted the state's chances for intervention. Especially big capital can easily and quickly escape from politically motivated regulation attempts (Scharpf 1988).

But we nonetheless must not interpret the relationship of the economy and the state based on a theory of fusion. Boccara $(1971,17)$ claims for example "the actions of monopolies and the capitalist state" work "as a single, uniform, organic totality that functions according to its own modalities". This assumption is put into doubt by the "(relative) autonomy of the state" that emerged from the co-operation of economic and state "action".

In the constitutional state, state initiatives and political decisions can come about that stand in a precarious relation to the economic valorisation imperatives of single corporations, branches and capital fractions (Graf 1993, 102).

It however seems to me that this autonomy is underpinned by a macabre dialectic:

The state and politics' relative autonomy enables diverse forms of stabilisation policies that the antagonistic and extremely dynamically differentiating capitalist society requires (more than ever). It is not least the relative autonomy operating under the conditions of an extensive politicisation of society and the liquefaction of the boundaries between politics and the economy, that, although in a contradictory manner, guarantees the political legitimatisation and ideological integration of the political system ${ }^{33}$ (Graf 1993, 102).

\footnotetext{
${ }^{33}$ It is obvious that the empirical-concrete form of state (political) action can only be analysed when it is related to the multiple conditions that determine its form in reality (Offe 1987). These conditions entail for example the specific form of state/political institutions and forms of regulation; the inner complexity of the political-administrative system; the sovereign territory's federal or centralised structure; the distribution of power between the government and the opposition; the dominant style of politics; political culture and its tradition; the integration of the nation state into supranational organisations and the resulting renunciation of sovereignty in respect to the political-administrative processing of problems and steering capacities; the direct influence exerted by social organisations and corporations that control large amounts of capital and personnel; etc. This topic cannot be further pursued in this context (see Dolata, Gottschalk and Huffschmid 1986).
} 
The historical-materialist theory of the media sees mediated communication in the context of the economic system, political/state organisations, and ideological integration. The qualities of this context and of its single moments shape communication. The principle implication is that the production of the media and the distribution of its contents have to adhere to capitalist and political imperatives because they are materially grounded in the economic and the political-administrative system. Historicalmaterialist media theory analyses this grounding in detail by making the media's organisational forms visible (Holzer 1992b). In what follows, we will use the example of the press, radio and television.

\subsection{The Media's Organisational Forms and Functions}

Germany's media were in the middle of the 1990s organised in five forms (ARD 1993, 234; Holzer 1989):

1. Private publishers (the press);

2. Private broadcasting that is publicly regulated (commercial broadcasting);

3. Public service broadcasting that is based on federal state law (ARD, ZDF);

4. Public service broadcasting that is based on federal law (Deutsche Welle, Deutschlandfunk);

5. Broadcasting run by the US administration (RIAS)

An obvious conclusion can be drawn. The media are subject to economic imperatives (the press, commercial broadcasting) as well as to demands defined by the statepolitical institutions of public service boards and councils (commercial broadcasting, ARD, ZDF, Deutsche Welle, Deutschlandfunk). The media's embedment into the economy and the state defines five economic and political functions they take on (Hund and Kirchhoff-Hund 1980, 96-103; Holzer 1990a, 200-201; Holzer 1973, 129137):

1. The capital-economic function: Production and sale of media products (press products, broadcasting programmes, advertisements, advertising times, etc.);

2. The function of commodity circulation: The creation of a climate fostering consumption and the advertisement of specific products and services;

3. The function of domination: Legitimation and propagation of society's organisational principle ${ }^{34}$, on which not just the media, but society as a totality is based;

4. The function of regeneration and reproduction of labour-power: Satisfaction of the audience's needs for information and entertainment that are oriented on the other functions;

5. The media sales and media market function: The media are markets for other media companies. We can call this aspect the media's sales and market function that has two manifestations: First, media organisations are buyers of relevant appliances, means of production and services (e.g. from the construction industry, the electrical industry, the chemical industry, the appliance industry, companies that produce films, television series and sound recordings). Second, especially broad-

\footnotetext{
${ }^{34}$ Note by the translator: Horst Holzer here does not specify what this organizational principle is. In another publication, Holzer $(1975,49)$ he points out: "Capitalism's principle of societalisation is the subsumption of living labour under capital's valorisation imperative" (German original: „Das Vergesellschaftungsprinzip des Kapitalismus besteht in der Subsumtion der lebendigen Arbeitskraft unter die Verwertungsimperative des Kapitals").
} 
cast organisations animate their audiences to act as buyers of receiving equipment.

\begin{tabular}{|c|c|c|c|}
\hline & Press & $\begin{array}{l}\text { Public service broad- } \\
\text { casting }\end{array}$ & $\begin{array}{c}\text { Commercial broad- } \\
\text { casting }\end{array}$ \\
\hline $\begin{array}{l}\text { Organisational } \\
\text { form }\end{array}$ & $\begin{array}{l}\text { Private capitalist publishers } \\
\text { with a high degree of monopo- } \\
\text { lisation }\end{array}$ & $\begin{array}{l}\text { Public service media } \\
\text { organisations as institu- } \\
\text { tions at the federal level } \\
\text { or the level of federal } \\
\text { states; broadcasting } \\
\text { councils (assemblies of } \\
\text { relevant societal groups) } \\
\text { control the programme-, } \\
\text { personnel- and invest- } \\
\text { ment-policies; there is } \\
\text { formal legal supervision } \\
\text { by the state }\end{array}$ & $\begin{array}{l}\text { Private capitalist corpo- } \\
\text { rations that broadcast } \\
\text { programmes based on } \\
\text { legally fixed conditions; } \\
\text { public service media at } \\
\text { the level of the federal } \\
\text { states and their councils } \\
\text { of relevant societal } \\
\text { groups supervise the } \\
\text { adherence to these } \\
\text { rules; the state legally } \\
\text { supervises private } \\
\text { broadcasters }\end{array}$ \\
\hline Steering principle & $\begin{array}{l}\text { Capitalist profit-orientation, } \\
\text { profit maximisation }\end{array}$ & $\begin{array}{l}\text { Policies that aim at the } \\
\text { integration of society as a } \\
\text { whole; the principles are } \\
\text { derived from the constitu- } \\
\text { tional foundations of capi- } \\
\text { talist democracies and are } \\
\text { formulated as criteria in } \\
\text { broadcast laws }\end{array}$ & $\begin{array}{l}\text { Capitalist profitability, } \\
\text { and policies that aim at } \\
\text { the integration of society } \\
\text { as a whole, but because } \\
\text { of profit interests have } \\
\text { "reduced requirements" } \\
\text { (Berg 1987, 268) }\end{array}$ \\
\hline \multicolumn{4}{|l|}{ Functions: } \\
\hline Economy & $\begin{array}{l}\text { Profit-oriented production of } \\
\text { press products and insofar as } \\
\text { a publisher holds a stake in } \\
\text { other media industries also of } \\
\text { films, television programmes, } \\
\text { music, etc. }\end{array}$ & $\begin{array}{l}\text { Broadcasters produce for } \\
\text { the national and interna- } \\
\text { tional programme market; } \\
\text { they to a specific degree } \\
\text { need to be oriented on } \\
\text { criteria of capitalist profit- } \\
\text { ability }\end{array}$ & $\begin{array}{l}\text { Profit-oriented produc- } \\
\text { tion of programmes for } \\
\text { the national and interna- } \\
\text { tional market }\end{array}$ \\
\hline $\begin{array}{l}\text { Commodity circu- } \\
\text { lation }\end{array}$ & $\begin{array}{l}\text { Support of advertising capital's } \\
\text { circulation; advertising of con- } \\
\text { sumer goods and services }\end{array}$ & $\begin{array}{l}\text { Support of advertising } \\
\text { capital's circulation; ad- } \\
\text { vertising of consumer } \\
\text { goods and services }\end{array}$ & $\begin{array}{l}\text { Support of advertising } \\
\text { capital's circulation; } \\
\text { advertising of consumer } \\
\text { goods and services }\end{array}$ \\
\hline Domination & $\begin{array}{l}\text { Legitimation of the economic } \\
\text { and political principles of or- } \\
\text { ganisation and domination that } \\
\text { constitute not just the press, } \\
\text { but also the individual and } \\
\text { societal existence of the read- } \\
\text { ers }\end{array}$ & $\begin{array}{l}\text { Legitimation of the eco- } \\
\text { nomic and political princi- } \\
\text { ples of organisation and } \\
\text { domination that constitute } \\
\text { not just broadcasting, but } \\
\text { also the individual and } \\
\text { societal existence of the } \\
\text { listeners and viewers }\end{array}$ & $\begin{array}{l}\text { Legitimation of the eco- } \\
\text { nomic and political prin- } \\
\text { ciples of organisation } \\
\text { and domination that } \\
\text { constitute not just com- } \\
\text { mercial broadcasters, } \\
\text { but also the individual } \\
\text { and societal existence of } \\
\text { the listeners and viewers }\end{array}$ \\
\hline $\begin{array}{l}\text { Regeneration and } \\
\text { reproduction of } \\
\text { labour-power }\end{array}$ & $\begin{array}{l}\text { Regeneration of the audience } \\
\text { via information, everyday help, } \\
\text { entertainment }\end{array}$ & $\begin{array}{l}\text { Regeneration of the audi- } \\
\text { ence via information, } \\
\text { everyday help, entertain- } \\
\text { ment }\end{array}$ & $\begin{array}{l}\text { Regeneration of the } \\
\text { audience via infor- } \\
\text { mation, everyday help, } \\
\text { entertainment }\end{array}$ \\
\hline $\begin{array}{l}\text { Media sales and } \\
\text { media markets }\end{array}$ & $\begin{array}{l}\text { Market for relevant media } \\
\text { products and means of media } \\
\text { production }\end{array}$ & $\begin{array}{l}\text { Market for relevant media } \\
\text { products and means of } \\
\text { media production }\end{array}$ & $\begin{array}{l}\text { Market for relevant me- } \\
\text { dia products and means } \\
\text { of media production }\end{array}$ \\
\hline
\end{tabular}

Table 1: The German media system in the 1990s

We have to keep in mind that competition shapes the realisation of the sketched functions. It is therefore not uncommon that this realisation falls victim to economic and/or state-political interests. This phenomenon becomes evident in the competition between and within single sectors (press, commercial broadcasting, ARD/ZDF, etc.). The massive intervention by the form of capital that produces and sells technologies, 
by associated political forces and state apparatuses considerably exacerbates this competition. So for example, the "combination" of the Federal Ministry for the Postal System and Telecommunications and large electronics corporations played a role in the introduction of cable and satellite broadcasting in Germany (Holzer 1989). It is also evident that specific economic and state-political interests can also collide in such processes. The German broadcasting dualism of ARD/ZDF is an example for competition that aims at the crowding out, or one could even say the destruction of a competitor (Holzer 1992a, 47-48).

Table 1 gives an overview of the status of the press, radio and television in Germany during the 1990s (see also Holzer 1980, 17-18).

The conditions and demands of the total societal (re-)production process shape in particular ways the functions of media organisations:

1. The quality of the media as sphere of production and (profit-oriented) sales indicates the existence of the mechanism inherent to the economic system that wants to "capitalise" as many activities and societal realms as possible.

2. The quality of the media as sphere of commodity advertisement indicates that any capitalist company faces the compulsion to constantly activate the relation between the commodity and money in order to rule out standstills in the transformation from commodity capital into monetary capital.

3. The quality of the media as sphere that secures domination and provides legitimation indicates the necessity of propagating society's organisation principle as obligatory orientation. It reminds us of the deficits in integration and motivation that especially under the extreme monopolisation of economic power shape the way of (re-)production and the way of life of broad segments of the population.

4. The quality of the media as sphere of regeneration indicates that the relations of life and production, and especially the development of the productive forces characteristic for capitalism, pose specific challenges for the socialisation, qualification and reproduction of working people and their families.

The economic and political functionalisation of mediated communication has decisive consequences for historical-materialist media theory that concern the creation of media programmes (articles, radio and television programmes) and the situation of media workers and recipients.

On the one hand, the functionalisation of the media defines requirements to which programmes' form and content have to adhere. This does not mean that programmes derive seamlessly from the media's functions. We can rather assume that in the context of a specific media organisation, there is a certain leeway in respect to the steering imperatives. The possibilities can be fairly limited, for example when the formal qualities or contents of programmes are rigorously put into the service of (advertising-)economic (mass press, commercial broadcasting) or political (ARD/ZDF's news programmes) directives. The possibilities can be larger when for example the demand for problematisation, critique and control has been asserted or is institutionally defined.

On the other hand, the integration of the media into the economy and state-politics delimits the framework under which media workers are active. They only have limited influence on the imperatives that shape workplaces and labour. Such influence essentially takes place via trade unions, the works councils, and the politics realised by unions and the small number of the members of parties and unions active in the 
committees of public service broadcasting organisations and publicly supervised media organisations.

Finally, the economic and political formation of the media implies that media communication is on the whole to the largest extent alienated from the control by those who make up the audience's vast majority. The economic and political participation of waged and salaried workers and their families rarely goes beyond the sale of labourpower and voting in elections. In the media, they are just "receivers" of offers. They constitute the "mass market" on which especially those, who control the media sector (highly concentrated press and broadcasting corporations on the one hand and media institutions constricted by state bureaucracy, party politics and capital interests on the other hand), want to realise the described functions. This mass market should therefore precisely be seen as what Negt and Kluge (1993, 13-17, 102, 146, 170) term "the public sphere of production": It forms the essential appendage to the monopolistic suppliers of press content and programmes and primarily serves these companies' strategies for achieving sales, fees and advertising revenues.

Historical-materialist media analysis has thus far altogether excluded the theme of media work because it has primarily taken a social theory and organisation theory approach. As a consequence, the analysis has faced the charge that it widely assumes an identity of media organisations and media workers (although one that is enforced by economic and state-political imperatives). In contrast, historicalmaterialist media theory has taken up the topics of the audience and the programme more intensively and systematically. The following section will treat these themes in the form of an example that concretises the argumentation that up to this point has been kept relatively abstract. The example is oriented on the German media's situation at the start of the 1990s. It refers to the media audience's (in quantitative terms) largest group whose favourite media are the press and television, to the political information that the press and television present, and to the entanglement of the audience's information demands and mediated political information's qualities.

\subsection{The Audience's Everyday Practices and Media Messages' Qualities}

The mass audience market is bound to the media because the latter instrumentalises the audience's use-value demands. Use-value demands in the context of the media's information and entertainment offers are rooted in the audience's everyday life, especially their workplaces, possibilities for the family's and cultural ("recreational") reproduction and regeneration, as well as participation rights that are granted or denied in working life, politics and culture.

Analyses have shown that the demands that the majority of audience members make on the media are provoked by the experience of the everyday quality of labour, regeneration and decision-making (Berg and Kiefer 1992). The constellation of instrumentalisation and alienation that shapes all central aspects of life seems to be an important trigger. Both tendencies especially affect the largest part of the audience that consists of the population's lower and middle strata and therefore profoundly shape this group's everyday consciousness and action as well as unconscious psychological activities (Holzer 1992a, 46-47; Holzer 1989; Hund and Kirchhoff-Hund 1980, 117-120) $)^{35}$ :

${ }^{35}$ The argumentation could be differentiated by the milieu-specific specification of the following topics ("social milieu" = "large groups of persons that can be discerned by group-specific forms of existence and increased internal communication" - Schulze 1992, 746). Schulze's approach can be utilised in media theory. It conceives of Germany's milieu structure as age 
1. The recipients experience themselves in working life, politics and culture ("free time") as extremely dependent, isolated, and in isolating and widely uninfluential positions in respect to the imperatives that these realms (that concern the recipients directly) control.

2. Economic, political and scientific-technological developments change everyday practices fundamentally and open up forms of live that erode traditional social milieus and pose opportunities for individualisation. These developments overburden the recipients. Most of these opportunities are difficult to follow, can hardly be influenced, and can, if at all, only be realised to a limited degree.

3. The recipients are increasingly confronted with social risks and the growing devastation of nature and the environment. These developments appear as apparently inevitable and unchangeable everyday occurrences. They tend to more evoke individual apathy and fear than resistance.

4. The dominant economic, political and cultural affairs and incidents are declared to be practical constraints, which keeps recipients from engaging with them more closely. The recipients are referred to worries about their individual conduct of life and to the amenities of individual recreation offers.

There is no doubt that at least a part of the audience does not experience the described constellation one-dimensionally, but as antagonism between subjection and resistance that manifests itself in demands for democracy, various initiatives and discussions in society (Beck 1996). So there is an antagonism between repression and the struggle for autonomy and self-competence. This struggle is based on the accumulation of potentials, risks and challenges in society and is directed against the valorisation and alienation pressures. But under the dominant conditions of society, the majority continues to face the dominance of the antagonism's first side (Brock 1993). It is therefore no surprise that the demands that audiences make on the media become more concrete in very specific ways. They favour media programmes that shall compensate for the pressurising quality of the realms of labour, reproduction, and decision-making (Heinze 1990, 146-147):

1. The audience favours to be offered contents that promise easing the burdens, compulsions and failures of everyday life in the family, labour and politics.

2. The audience favours to be offered orientation data that can be used in the short term, trivialises, make their immediate personal requirements and everyday living conditions readily comprehensible and mangeable.

3. The audience favours contents that interpret life as problem-free, and put the personal situation into a comprehensible, indubitable and authoritatively motivated context.

Because of its political-economic constitution, the media to which the audience turns is and has to be oriented on realising the audience's use-value demands. The synchronisation of the media's offers and the audience's demands forms the foundation of the media's existence. There are two implications. On the one hand, the media

and educational groups (18-40, elementary school-leaving certificate; $18-40$, secondary school-certificate; 40-70, elementary school-leaving certificate; 40-70, secondary schoolcertificate, etc.) in respect to their milieu membership (milieus in respect to entertainment, self-realisation, harmony, integration, etc.) and everyday aesthetical schema (tabloid culture, suspense culture, high culture). 
with their offers attends to the audience's wishes. It is essentially oriented on constantly binding the audience's interests to the offered information, entertainment and advertisements. On the other hand, the media confirms these relations by engaging with the consequences of labour, reproduction and decision-making, i.e. with the audience's use-value demands that are motivated by the psychological need for compensation.

We can say that the media act according to the interests and demands that the societal shaping of living conditions impresses on the audience members, be they individuals or families. It is evident that the audience's demands are oriented on seeking psychological compensation for the conditions under which the majority suffers. The point is not to discredit the audience's use-value demands. The point is rather that we want to criticise the process that fixes the audience to its compensatory orientation and instrumentalises this intransparent orientation in the interest of domination.

We do not insinuate that the media's offers and the audience's use-value demands are in a pre-stabilised harmony. We also do not want to suggest that the "(media-)organisers" are "cunning felons" and that the users are "helpless victims". The analysis is neither about one side's disingenuousness nor about the other side's powerlessness. We also cannot assume that the contents of the media's offers and/or the qualities of the audience's preferences decide on whether and in what form the media's contents meet the audience's demands. The decisive aspect is rather made up by the audience's social and psychological characteristics, experiences and refusals, hopes and fears, orientations and assessments, possibilities and limits that are communicated as partly consciously and partly unconsciously active "habitus" throughout the totality of its life course (Bourdieu 1984).

The context of life constitutes without a doubt the "underground" of the audience's use-value demands. But life cannot be reduced to this aspect. The context of life rather on the one hand embodies the contexts of everyday family life, labour, leisure and politics. On the other hand the context of life also forms the network of individual and societal topics, demands, problems, risks and opportunities, in which human existence takes place. The audience turns to the media based on its (compensatory) demands. But the audience does not relate the media's content purely to its own demands, but to the totality of its conditions of life and development. The totality of the audience's objective and subjective "everydaynesses" (Alltäglichkeiten) evinces whether the media offer poses a useful answer. Practical action that is subject to the dialectic of repressive facts and the pursuit for self-defined autonomy is in the last instance the decisive factor in this everydayness of the audience. The same totality evinces whether the audience considers the delivery of instant knowledge, recipes for orderliness and amusement as too light. The rejection of such offers could take place because the audience members are alienated from the conditions of existence they experiences and suffer from in their everyday life or because such knowledge only offers pseudo-solutions. The congruence of media offers and audience demands cannot or can at most in the short term cover up the latter condition. The reason is that the satisfaction of demands quickly turns out to be without (use-)value when despite media consumption the audience's social and psychological problems that create such demands remain unaffected and unsolved and when the audience's readiness to see through such problems and engage with them is disregarded.

The just sketched audience makes up the majority of the readers and viewers of the press and (commercial and public service) television (Media Perspektiven 1991). How the audience's demands on the media and media programmes are entangled is 
strikingly demonstrated by the ways of how the audience's dispositions and the qualities of political information offered by the press and television mutually interact.

Analyses of programmes have shown that the largest part of political information in the press and on television has a personalising character (Robes 1990; Holzer 1989, 129-130; Holzer 1992b). Such studies have also revealed what personalisation, in our case the personalisation of socio-political facts and events, as journalistic technology means. This technology dissolves socio-political topics into individuals and their attributes or makes them appear as décor made up by personality stories and individual destinies. We do not criticise that such topics, their causes and consequences, are presented and have to be presented with a focus on individuals. The problem rather is that the technology of personalisation deforms political topics. Political topics are presented as "over-subjectified": They are decoupled from any (transparent) connection to their foundations in society and society's structures. They are presented as superficial, emotionally appealing personal data. And it is a problem that in personalised political information, socio-political developments are presented as a conglomeration of "events" that only form a scenery whose specifically societal qualities are erased: The depicted individuals become reified pawns of uncomprehended societal relations.

Personalisation becomes vividly evident especially in the celebration of the socalled personalities of public life who are presented in news shows, political magazines, discussion panels, personality and talk shows on television as well as in magazines and the yellow press' illustrated stories. Such media content allows us to observe the metamorphosis of socio-political topics into individual problems informed by human interest or into dramas featuring photogenic and telegenic celebrities. The way (political) celebrities are presented poses a succinct example for a personality cult and a conception of history and society, in which history and society are meeting places of individuals that conduct the course of the world (with whatever positive or negative consequences) motivated by their personal situation and tempers, albeit they are encircled by national and global crises and hostile opponents. But not only the big ones are put into the media spotlight. Ordinary people's everyday fate is used for presenting socio-political developments as pieces and ornaments of the intimate, private struggle for survival. The societal relations and problems that explain such struggles are not covered ${ }^{36}$.

The entanglement of political information and the audience's dispositions comes about through the mediation of the personalising conception of history and society.

1. The response to the audience's interest in trivialised orientation data for short-term use are handy, telegram-like news-"details" and short infotainment programmes whose weightiness and authority results from human experiences that the presented material's "interesting" character opens up.

2. The desire for an interpretation of life without problems and that promises order is reflected in programmes by a type of personalisation that transforms existing society's structural violence into manageable, arrangeable, organisable personal qualities as well as into inter- and intra-personal relations and conflicts.

${ }^{36}$ It is well known that journalism focused on presenting catastrophes plays a crucial role in both scenarios of individualisation. "Catastrophes [...] are the day's highlight. [...] The chief editor says, 'The audiences want to see how the shack burns and not just its smoking beams"' (Die Zeit 1988). 
3. The media respond to the audience's desire for relief from everyday denials and coercion by, despite all rigours, adversities and disappointments, putting humans into the centre of all presented events.

The audience's reaction to political information that is arranged in such a way becomes especially evident in the context of television news ${ }^{37}$. The available studies show that news programmes are at the forefront of advancing the personalisation and subjectification of socio-political developments and the fragmentation of news into unconnected details. Such studies also show that personalised political programmes are especially popular among the lower and middle social strata (Berg and Kiefer 1992, Hoffmann 1982, Renckstorf 1980, Renckstorf and Rohland 1980, Schulz 1976). The audience seems to positively assess the programmes first of all because the latter disassemble "complex" world affairs into a bundle of event bits oriented on individuals. These bits are made comprehensible, clear, "human" and "handy" with the help of presenters, who act as "guarantors" for the informational content. The analyses assess news programmes in most cases as trivialisations and personalised-personalising news staccato. But for wide parts of the audience such news embodies transparency, completeness, truth and above all order in the chaos of events (that are apparently experienced as chaos). It is interesting to see that news programmes are particularly praised when they present the political "helmspeople" who take decisions and the "ordinary people" who enforcedly have to suffer from these decisions as people just like you and me. This modus of presentation obviously creates a climate that makes society appear as human and all-too-human even in times of war, crises, scandals, and catastrophes. The reason why the majority of the audience accepts the personalisation of socio-political developments obviously seems to be that such programmes are for many viewers a means of compensation against the experience of their living conditions as abstract, anonymous, unclear, and isolating. An essential factor is that the news creates an identity of the presented topics and individuals. The latter not just include the relevant "public" actors, but also the news presenters. By staging the presented politicians or presenters as experts obliged to give information and mediated by personalisation, the audience gets the impression that it directly participates in the reported events. Also in this context it seems that personalisation compensates for conditions of alienation that confront many audience members. Such alienation seems to come from extremely dependent positions in labour, politics and culture ("free time") that hardly allow the individuals to exert influence. It does not become evident to many audience members that the news practices "the staging of instead of checking politics" (Landfried 1993, 193). It also becomes hardly evident to them that the alleged participation in political events is exhausted in the identification with the presented individuals, who as typical figures of the dominant political order remain inscrutable (Holly, Kühn and Püschel 1986).

We albeit have to assume that the discussed identity of informational offers and audience dispositions has a limited and instable character because of the following reasons: First, we have to concede that the incriminated information does not reach many of the (possible) audience members or does not influence them. Second, we have to remind us that the political information disseminated by television and the press does not just contain personalised and event-oriented interpretations of reality.

\footnotetext{
${ }^{37}$ This is the case for ARD/ZDF as well as for commercial television corporations. By "news", we understand news programmes (ARD-Tagesschau, ZDF-Heute, SAT 1-TopNews, Pro 7Nachrichten) as well as news journals (ARD-Tagesthemen, ZDF-Heute Journal, RTL-aktuell, SAT 1-Newsmagazin).
} 
Third, the "congruence" seems to become fragile when the audience cannot relate its everyday living conditions, demands and experiences to the offered information. But despite these limitations, we cannot ignore one circumstance: The majority of publications and television programmes (in the case of ARD/ZDF a bit less than in the case of commercial corporations) is dominated by the type of political information we described. The (suspected) effects of such a massive "instruction" that over and over impinges on the audiences should not be trivialised. The analysis of political information in the press and television must especially focus on the transformation of many readers and viewers into collectors of personal data and actualities. Taking on such a status makes sure that that the subjects and society's insights into social reality are decisively hindered. Social reality is substituted by a salmagundi of personalised "throw away information" (Wember 1976, 61) and a "shattered world of particulars" (Enzensberger 1962).

\section{References}

ARD, ed. 1993. ARD Jahrbuch 93. Hamburg: Hans Bredow Verlag.

Autorenkollektiv. 1974. Sprachliche Kommunikation. Berlin: Akademie-Verlag.

Beck, Ulrich. 1996. The Reinvention of Politics. Rethinking Modernity in the Global Social Order. Cambridge: Polity Press.

Berg, Klaus. 1987. Grundversorgung. Media Perspektiven 5: 265-274.

Berg, Klaus and Marie-Luise Kiefer, eds. 1992. Massenkommunikation IV. Eine Langzeitstudie zur Mediennutzung und Medienbewertung 1964-1990. Frankfurt am Main: Nomos.

Bisky, Lothar. 1986. Zum Einfluß imperialistischer Masssenmedien auf das Alltagsbewußtsein Jugendlicher in kapitalistischen Staaten. Wissenschaftliche Zeitschrift der Humboldt Universität zu Berlin, Gesellschaftswissenschaftliche Reihe 35 (5): 369-373.

Bisky, Lothar. 1978. Massenkommunikation und soziales Handeln Communications: The European Journal of Communication Research 4 (3): 289-301.

Bisky, Lothar. 1976. Zur Kritik der bürgerlichen Massenkommunikationsforschung. Berlin: Deutscher Verlag der Wissenschaften.

Boccara, Paul. 1971. Zum staatsmonopolistischen Kapitalismus. Sozialistische Politik 11.

Böke, Henning. 1993. Zur Konstruktion des Sozialen. Eine Auseinandersetzung mit Ernesto Laclau und Chantal Mouffe. Z - Zeitschrift Marxistische Erneuerung 13: 165-173.

Bourdieu, Pierre. 1984. Distinction: A Social Critique of the Judgement of Taste. London: Routledge.

Brock, Ditmanr. 1993. Wiederkehr der Klassen? Über Mechanismen der Integration und der Ausgrenzung in entwickelten Industriegesellschaften. Soziale Welt 44 (2): 177-198.

Die Zeit. 1988. Seid ihr alle da? Ein Blick auf die tägliche Nachrichten-Schau von RTL plus. Die Zeit, September 17, 1988.

Dolata, Ulrich, Arno Gottschalk and Jörg Huffschmid 1986. Staatsmonopolistische Komplexe als neue Organisationsform des Kapitals. In Krisentyp der 80er Jahre: Kapitalstrategien Entwicklungsvarianten - Alternativen. Marxistische Studien: Jahrbuch des IMSF 11, ed. IMSF, 222-247. Frankfurt am Main: Institut für Marxistische Studien und Forschungen.

Enzensberger, Hans Magnus. 1962. Einzelheiten I. Frankfurt am Main: Suhrkamp.

Erckenbrecht, Ulrich. 1973. Marx' materialistische Sprachtheorie. Mit einem selektiven Sachregister zu den Marx-Engels-Werken. Kronberg/Ts: Scriptor.

Esser .Josef 1985. Staat und Markt. In Politikwissenschaft. Begriffe - Analysen - Theorien. Ein Grundkurs, ed. Iring Fetscher and Herfried Münkler. 201-244. ed. Reinbek:

Graf, Ralph. 1993. Der Staat im entwickelten Kapitalismus - Koloß auf tönernen Füßen? Z Zeitschrift Marxistische Erneuerung 14: 97-108.

Habermas, Jürgen. 1993. Justification and Application: Remarks on Discourse Ethics. Cambridge, MA: The MIT Press. 
Habermas, Jürgen. 1988. Actions, Speech Acts, Linguistically Mediated Interactions, and the Lifeworld. In On the Pragmatics of Communication, ed. Maeve Cooke, 215-255. Cambridge: Polity.

Habermas, Jürgen. 1987. The Philosophical Discourse of Modernity. Twelve Lectures. Cambridge: Polity.

Habermas, Jürgen. 1976. Zur Rekonstruktion des historischen Materialismus. Frankfurt am Main: Suhrkamp.

Heinze Thomas. 1990. Medienanalyse: Ansätze zur Kultur- und Gesellschaftskritik. Opladen: Westdeutscher Verlag.

Hoffman, Burkhard et al. 1983. After the Frankfurt School. Media, Culture \& Society 5 (1): 7 116.

Hoffmann, Jürgen 1987. Von der Vollbeschäftigung zur Politik der Deregulierung. Ökonomische und soziale Strukturveränderungen in der Bundesrepublik 1967-1985 und der sich daraus ableitende Korridor politischen Handelns. In Arbeitsmarkt, Arbeitsbeziehungen und Politik in den 80er Jahren, ed. Heidrun Abromeit and Bernhard Blanke, 344363. Opladen: Westdeutscher Verlag.

Hoffmann, Rolf-Rüdiger. 1982. Politische Fernsehinterviews: Eine empirische Analyse sprachlichen Handelns. Tübingen: Max Niemeyer Verlag.

Holly, Werner, Peter Kühn and Ulrich Püschel. 1986. Politische Fernsehdiskussionen. Zur medienspezifischen Propaganda als Diskussion. Tübingen: Max Niemeyer Verlag.

Holzer, Horst. 1992a. Köder und Haken zugleich. Der Faktor „Unterhaltung“ im „dualen“ Fernsehen. medium 22: 45-48.

Holzer, Horst. 1992b. Massenkommunikation als Kapitalverwertungsprozeß und die Rolle des Publikums. In Kommunikationstheorien: Ein Textbuch zur Einführung, ed. Roland Burkhart and Walter Hömberg, 69-90. Wien: Braumüller.

Holzer, Horst. 1990a. Politische Ökonomie der Massenmedien. In Grundbegriffe der Medienpädagogik, ed. Jürgen Hüther, Bernd Schorb, and Christiane Brehm-Klotz, 198-201. Böblingen: expert-Verlag.

Holzer, Horst. 1990b. Massenkommunikation. In Europäische Enzyklopädie zu Philosophie und Wissenschaften, Band 3, ed. Hans-Jörg Sandkühler, Hamburg: Meiner.

Holzer, Horst. 1989. Die Privaten. Kommerz in Funk und Fernsehen. Köln: Pahl-Rugenstein. Holzer, Horst. 1980. Medien in der BRD. Entwicklungen 1970-1980. Köln: Pahl-Rugenstein. Holzer, Horst. 1973. Kommunikationssoziologie. Reinbek bei Hamburg: Rowohlt.

Hund, Wulf D. 1976. Ware Nachricht und Informationsfetisch. Zur Theorie der gesellschaftlichen Kommunikation. Darmstadt \& Neuwied: Luchterhand.

Hund, Wulf D. and Bärbel Kirchhoff- Hund. 1980. Soziologie der Kommunikation. Reinbek: Rowohlt.

Jürgens, Ekkehardt. 1985. Die List der Vernunft und ihre Grenzen in der Geschichte. Zum historischen Verhältnis von Medienentwicklung und Gesellschaftsfortschritt. In Totale Bildschirmherrschaft, ed. Klaus Betz and Horst Holzer, 11-30. Köln: Pahl-Rugenstein. $2^{\text {nd }}$ edition.

Krüger, Hans-Peter. 1986. Kommunikatives Handeln oder gesamtgesellschaftliche Kommunikationsweise. In Kommunikatives Handeln. Beiträge zu Jürgen Habermas' Theorie des kommunkativen Handelns, ed. Axel Honneth and Hans Hoas, 216-254. Frankfurt am Main: Suhrkamp.

Laclau, Ernesto and Chantal Mouffe. 2001. Hegemony and Socialist Strategy. Towards a Radical Democratic Politics. London: Verso. Second edition.

Landfried, Christine 1991. Die Macht des Fernsehens, Inszenierung statt Kontrolle von Politik. In Regieren in der Bundesrepublik 3. Systemsteuerung und "Staatskunst“, ed. HansHermann Hartwich and Göttrik Wewer, 193-214. Opladen: Leske + Budrich.

Marx, Karl. 1857/1858. The Grundrisse. London: Penguin.

Marx, Karl. 1849. Wage Labour and Capital. In Marx \& Engels Collected Works (MECW), Volume 9, 197-228. London: Lawrence \& Wishart. 
Marx, Karl and Friedrich Engels. 1846. The German Ideology. Amherst, NY: Prometheus.

Media Perspektiven, ed. 1991. Daten zur Mediensituation in Deutschland. Frankfurt am Main: Arbeitsgemeinschaft Rundfunkwerbung.

Mocek, Reinhard. 1991. Autopoiese als Herausforderung. Aspekte von Kritik und Zustimmung aus marxistischer Sicht. In Zur Biologie der Kognition. Ein Gespräch mit Humberto

R. Maturana und Beiträge zur Diskussion seines Werkes, ed. Volker Riegas and Christian Vetter, 264-280. Frankfurt am Main: Suhrkamp.

Negt, Oskar and Alexander Kluge. 1993. Public Sphere and Experience: Toward an Analysis of the Bourgeois and Proletarian Public Sphere. Minneapolis, MN: University of Minnesota Press.

Offe, Claus. 1987. Die Staatstheorie auf der Suche nach ihrem Gegenstand. Beobachtungen zur aktuellen Diskussion. In Jahrbuch zur Staats- und Verwaltungswissenschaft, Band 1, ed. Thomas Ellwein, Joachim Jens Hesse, Renate Mayntz and Fritz W. Scharpf, 309-320. Baden-Baden: Nomos.

Renckstorf, Karsten. 1980. Nachrichtensendungen im Fernsehen (1): Zur Wirkung von Darstellungsformen in Fernsehnachrichten. Berlin: Spiess.

Renckstorf, Karsten and Lutz Rohland. 1980. Nachrichtensendungen im Fernsehen (2): Absichten, Interessen und Mustr der Medienzuwendung - Konturen des aktiven Publikums. Berlin: Spiess.

Robes, Jochen. 1990. Die vergessene Theorie: Historischer Materialismus und gesellschaftliche Kommunikation. Zur Rekonstruktion des theoretischen Gehalts und der historischen Entwicklung eines kommunikationswissenschaftlichen Ansatzes. Stuttgart: Silberburg.

Scharpf, Fritz. 1988. Verhandlungssysteme, Verteilungskonflikte und Pathologien der politischen Steuerung. MPIfG Discussion Paper 88/1.

Schulz, Winfried. 1976. Die Konstruktion von Realität in den Nachrichten: Analyse der aktuellen Berichterstattung. Freiburg im Breisgau: Alber.

Schulze, Gerhard. 1992. Die Erlebnisgesellschaft. Kultursoziologie der Gegenwart. Frankfurt am Main: Campus.

Vieweger, Dieter. 1983. Semantik und Sprechakttheorie. In Richtungen der modernen Semantikforschung, ed. Wolfgang Motsch and Dieter Vieweger, 145-245. Berlin: AkademieVerlag.

Wember, Bernward 1976. Wie informiert das Fernsehen? München: List.

\section{About the Authors}

Horst Holzer (1935-2000) was a German sociologist and communication theorist. He contributed to the formation and development of the critique of the political economy of media and communication in the German-speaking world. Holzer used Marxist theory for the analysis of the relationship between capitalism and communication. Given his pioneering intellectual role in the development of the critique of the political economy of communication in the Germanspeaking world, it is not an understatement to say that Horst Holzer is Germany's Dallas Smythe. Holzer lived and worked in Munich and published twenty German books. The focus of Holzer's writings was in general on communication theory, the sociology of communication, as well as on capitalism and communication. In particular, his books were about the ideology and political economy of magazines, newspapers, radio and television; public sphere theory, sociological theories, children and television, and surveillance.

Christian Fuchs is a critical theorist, critical political economist, and the co-editor of the journal tripleC: Communication, Capitalism \& Critique. @fuchschristian http://fuchs.uti.at 